\title{
Hygroscopic behavior of aerosols generated from solutions of 3-methyl-1,2,3-butanetricarboxylic acid, its sodium salts, and its mixtures with $\mathrm{NaCl}$
}

\author{
Li Wu ${ }^{1}$, Clara Becote ${ }^{2,3,4}$, Sophie Sobanska ${ }^{2}$, Pierre-Marie Flaud ${ }^{3,4}$, Emilie Perraudin $^{3,4}$, Eric Villenave Pe, $^{3,4}$ \\ Young-Chul Song ${ }^{1}$, and Chul-Un Ro ${ }^{1}$ \\ ${ }^{1}$ Department of Chemistry, Inha University, Incheon, South Korea \\ ${ }^{2}$ Institut des Sciences Moleìculaires, UMR CNRS 5255, University of Bordeaux, Talence, France \\ ${ }^{3}$ University of Bordeaux, EPOC, UMR 5805, 33405 Talence CEDEX, France \\ ${ }^{4}$ CNRS, EPOC, UMR 5805, 33405 Talence CEDEX, France
}

Correspondence: Chul-Un Ro (curo@inha.ac.kr)

Received: 30 April 2020 - Discussion started: 29 May 2020

Revised: 13 October 2020 - Accepted: 13 October 2020 - Published: 20 November 2020

\begin{abstract}
MBTCA (3-methyl-1,2,3-butanetricarboxylic acid), a low-volatile, highly oxidized, secondary-generation product of monoterpenes, is one of the most relevant tracer compounds for biogenic secondary organic aerosols (SOAs). In this study, laboratory-generated, micrometersized, pure-MBTCA, mono-/di-/trisodium MBTCA salts and MBTCA-NaCl mixture aerosol particles of four mixing ratios (molar ratios $=1: 1,1: 2,1: 3$, and $2: 1$ ) were examined systematically to observe their hygroscopic behavior by varying the relative humidity $(\mathrm{RH})$ using in situ Raman microspectrometry (RMS) assembled with either a see-through impactor, where the particles were deposited on a $\mathrm{Si}$ wafer, or a levitation system. The pure MBTCA droplets effloresced at $\mathrm{RH}=\sim 30 \%-57.8 \%$ and did not deliquesce until $\mathrm{RH}>95 \%$. The mono- and disodium MBTCA salt aerosols did not show clear efflorescence RH (ERH) and deliquescence RH (DRH). In contrast, the trisodium MBTCA salt exhibited $\mathrm{ERH}=\sim 44.4 \%-46.8 \%$ and $\mathrm{DRH}=\sim 53.1 \%$ during the hygroscopic experiment cycle. The mixture aerosols generated from solutions of MBTCA $: \mathrm{NaCl}=1: 1$ and 2:1 showed no visible ERH and DRH in the see-through impactor because of the partial and total consumption of $\mathrm{NaCl}$, respectively, through chemical reactions during the dehydration process. The mixture particles with a $1: 1$ molar ratio in the levitation system exhibited a clear DRH at $\sim 71 \%$ and ERH at $\sim 50 \%$. This suggests less reaction between the mixtures and a larger portion of $\mathrm{NaCl}$ remaining in the levitation system. The other mixtures
\end{abstract}

of MBTCA: $\mathrm{NaCl}=1: 2$ and $1: 3$ displayed single-stage efflorescence and deliquescence at $\mathrm{ERH}=\sim 45 \%-50 \%$ and $\mathrm{DRH}=\sim 74 \%$, respectively, because of the considerable amount of $\mathrm{NaCl}$ present in the mixture aerosols in both systems. Observations and Raman analyses indicated that only monosodium MBTCA salt aerosols could be formed through a reaction between MBTCA and $\mathrm{NaCl}$. The reaction occurred more rapidly with a more elevated concentration of either MBTCA or $\mathrm{NaCl}$, and the controlling factor for the reactivity of the mixtures depended mostly on the availability of $\mathrm{H}^{+}$dissociated from the MBTCA tricarboxylic acid. The lower degree of reaction of the mixture particles in the levitation system might be caused by the relatively airtight circumstance inside, i.e., less release of $\mathrm{HCl}$. The study revealed that the interactions between the MBTCA and $\mathrm{NaCl}$ could modify the properties of the organic acid in the atmosphere, leading to enhanced capability of the probable heterogeneous chemistry in the aqueous aerosols.

\section{Introduction}

Chemical processes, such as gas-phase oxidations of airborne biogenic and anthropogenic volatile organic compounds (VOCs) by ozone $\left(\mathrm{O}_{3}\right)$, hydroxyl radical $(\mathrm{OH})$, and nitrate radical $\left(\mathrm{NO}_{3}\right)$ and their condensed-phase reactions with preexisting aerosols can promote the formation 
of increasingly oxidized and less volatile secondary organic aerosols (SOAs). SOAs are a ubiquitous and dominant fraction of the fine-aerosol mass that exists as liquid, amorphous solid, semisolid, and phase-separated aerosol particles (Jang et al., 2002; Hallquist et al., 2009; Jimenez et al., 2009; Virtanen et al., 2010; Koop et al., 2011; Bateman et al., 2015b; Shrivastava et al., 2015; Bernard et al., 2016; Pajunoja et al., 2016; Freedman, 2017; Shrivastava et al., 2017; Kim et al., 2018; Srivastava et al., 2018; Liu et al., 2019; Slade et al., 2019; Song et al., 2019; Wu et al., 2019a). These aerosols are of critical importance because of their ability to scatter and absorb solar radiation directly, to affect the number of CCN (cloud condensation nuclei) through the formation of new particles and the growth of preexisting particles, and further impact the climate and human health (Haywood and Boucher, 2000; Topping et al., 2013; Pöschl and Shiraiwa, 2015; Reid et al., 2018; Marsh et al., 2019). SOAs are highly dynamic, multiphase chemical systems with a range of volatility and solubility, and model simulations have claimed that the phase state of SOAs differs according to the global locations and altitudes, with an evolving relative humidity (RH), temperature, and particle composition (Kroll and Seinfeld, 2008; Shiraiwa et al., 2017).

Oxidative products of biogenic VOCs, such as monoterpenes (e.g., $\alpha$ - and $\beta$-pinenes), act as a dominant source of SOAs as they have high emission rates on a global scale and give considerable SOA yields, and they play a central role in new particle formation (Guenther et al., 1995; Lignell et al., 2013; Mutzel et al., 2016; Holopainen et al., 2017). Carboxylic-acid-containing organic compounds comprise a large fraction of SOAs in the Northern Hemisphere (Yatavelli et al., 2015). An extremely low-volatile tricarboxylic acid, 3methyl-1,2,3-butanetricarboxylic acid (MBTCA; $\mathrm{C}_{8} \mathrm{H}_{12} \mathrm{O}_{6}$ ), has become one of the most relevant tracer compounds for terpene SOAs (Jaoui et al., 2005; Szmigielski et al., 2007; Zhang et al., 2010; Donahue et al., 2012; Müller et al., 2012; Lai et al., 2015; Sato et al., 2016). In addition, it is also one of a few well-known compounds with a high $\mathrm{O}: \mathrm{C}$ ratio that is formed in the oxidation of VOCs (Dunne et al., 2016). MBTCA is a second- or later-generation reaction product from monoterpenes by the $\mathrm{OH}$-initiated oxidation of pinonic acid (PA) in the gaseous and aqueous phases and even at the air-water interface (Müller et al., 2012; Praplan et al., 2012; Aljawhary et al., 2016; Enami and Sakamoto, 2016). The MBTCA concentrations were found to be positively correlated with temperature because of the enhanced photochemical production of $\mathrm{PA}$ by $\mathrm{OH}$ radicals with increasing temperature (Hu et al., 2008; Zhang et al., 2010; Gómez-González et al., 2012; Miyazaki et al., 2012). A further reaction between MBTCA and $\mathrm{OH}$ radicals can result in $\mathrm{CO}_{2}$ loss (Kostenidou et al., 2018). MBTCA was first observed in the Amazon Basin and in summer aerosols from Ghent, Belgium (Kubátová et al., 2000; Kubátová et al., 2002). The compound was later found in the USA (Jaoui et al., 2005), Europe (Fu et al., 2009; Kourtchev et al., 2009; Zhang et al., 2010; Yasmeen et al., 2011; Gómez-González et al., 2012; Vogel et al., 2013; Kammer et al., 2018; Vlachou et al., 2019), Japan (Miyazaki et al., 2012), the polar regions (Hu et al., 2013), China (Hu et al., 2008; Ding et al., 2012; Li et al., 2013; Fu et al., 2014; Kang et al., 2018; Hong et al., 2019), and Australia (Cui et al., 2019). In addition, it has been observed in forest, marine, mountainous, urban, and rural aerosols, with its levels ranging from 0.03 to $100 \mathrm{ng} \mathrm{m}^{-3}$, and the level was generally higher in the fine-particle fraction than in the coarse fraction (Zhang et al., 2010).

The ability of the aerosol particles to take up water in the air is dependent on one of the most important physicochemical properties, i.e., the hygroscopicity (Jimenez et al., 2009; Chu et al., 2014; Tang et al., 2019; Wu and Ro, 2020). Hygroscopicity can help better understand the (i) aerodynamic properties, (ii) cloud droplet nucleation efficiency, (iii) optical properties, and (iv) physicochemical changes through complicated heterogeneous chemical reactions of aerosol particles with various atmospheric gas-phase species. MBTCA was predicted to partition significantly into aerosol liquid water (ALW; Aljawhary et al., 2016). Therefore, a study on the hygroscopic behavior of MBTCA is important for understanding its phase states better when it interacts with water vapor at different RHs as well as its impacts on heterogeneous chemical reactions, atmospheric environment, and human health (Parsons et al., 2004; Mikhailov et al., 2009; Bateman et al., 2015a; Freedman, 2017; Slade et al., 2019). Atmospheric particles typically involve complex internal mixtures of organic and inorganic compounds (Shrivastava et al., 2017; Karadima et al., 2019). The interactions between organic and inorganic compounds may alter the chemical compositions of SOAs, which in turn affect their physicochemical properties, such as hygroscopicity (Rudich et al., 2007; Wu et al., 2011; Wang et al., 2015; Jing et al., 2016; Wang et al., 2018). Dicarboxylic acids (DCAs) can undergo reactions with inorganics, such as $\mathrm{NaCl}$, resulting in $\mathrm{Cl}$ depletion and $\mathrm{HCl}$ liberation (Ma et al., 2013; Li et al., 2017). On the other hand, the interactions between tricarboxylic acids and inorganics have never been investigated.

In this study, in situ Raman microspectrometry (RMS) was used to examine the hygroscopic behavior, evolution of the chemical composition, phase states, and microstructures as well as chemical reactivity of laboratory-generated, micrometer-sized aerosols generated from a pure MBTCA solution, mono-/di-/trisodium MBTCA salt solutions, and MBTCA-NaCl mixture solutions. RMS was assembled with either a see-through impactor, where the particles were deposited on a Si wafer, or a levitation system. The particles on the Si wafer were exposed to a hygroscopic measurement cycle, where they experienced a dehydration process first (by decreasing RH from $\sim 95 \%$ to $\sim 1 \%$ ), followed by a humidification process (by increasing $\mathrm{RH}$ from $\sim 1 \%$ to $\sim 95 \%$ ). The particles in the levitation system experienced a humidification process first (by increasing the RH from $\sim 10 \%$ to $\sim 80 \%$ ) after quenching from droplets, followed 
by a dehydration process (by decreasing RH from $\sim 80 \%$ to $\sim 10 \%)$. The deposited particles $(\sim 6.5 \mu \mathrm{m}$ size on average in this study) may have some influences from the collecting substrate such as a facilitated heterogeneous nucleation, which can be eliminated in the levitation system due to the substrate-free and contactless properties. However, the particles in the levitation system are generally large in size ( $\sim 80 \mu \mathrm{m}$ on average in this study), which is less atmospherically relevant. And thus, the analysis of the particles in both systems is expected to give more detailed information on the hygroscopic behavior of MBTCA aerosols. $\mathrm{NaCl}$, one of the major components of marine aerosols, was selected as the inorganic component since it was previously reported that organic acids contributed significantly to $\mathrm{Cl}$ depletion through a reaction with $\mathrm{NaCl}$ (Laskin et al., 2012). In situ Raman analysis could clearly identify MBTCA and its sodium salts during the hygroscopicity measurement despite $\mathrm{NaCl}$ being Raman inactive. To the best of the authors' knowledge, this is the first study on the hygroscopic behavior and chemical reactivity of MBTCA and its sodium salts thus far. The results are expected to promote more precise thermodynamic models (Clegg et al., 2003). The phase transitions were observed by monitoring the size changes together with the Raman spectra evolutions of the aerosol particles as a function of the RH. RMS can provide information on chemical functional groups, water contents, molecular interactions, and phase states of the aerosol particles. Such data can help understand the hygroscopic behavior of complex aerosol particles better (Lee et al., 2008; Li et al., 2017; Wang et al., 2017). The molecular characterization of organic aerosols can provide better insights into the potential mechanisms of SOA formation and transformation (or aging; Hallquist et al., 2009). Scanning electron microscopy (SEM)-energy-dispersive Xray spectroscopy (EDX) mapping was used to examine the elemental composition distribution in effloresced particles.

\section{Experimental section}

\subsection{Sample preparation}

Pure $0.3 \mathrm{M}$ solutions of $\mathrm{NaCl}$ ( $>99.9 \%$ purity, SigmaAldrich) and MBTCA (98\%; Toronto Research Chemicals, TCR) were prepared. The mixture solutions of MBTCA and $\mathrm{NaCl}$ were prepared with molar mixing ratios of MBTCA $: \mathrm{NaCl}=1: 1,1: 2,1: 3$, and $2: 1$. Mono-/di/trisodium MBTCA salt solutions were obtained by mixing MBTCA and $\mathrm{NaOH}$ ( $>99.9 \%$ purity; Sigma-Aldrich) with molar ratios of $\mathrm{MBTCA}: \mathrm{NaOH}=1: 1,1: 2$, and $1: 3$, respectively. A mixture solution of MBTCA and monosodium MBTCA salt with a molar mixing ratio of $1: 1$ was prepared as well. All the solutions were made by dissolving the chemicals in the ultrapure deionized (DI) water (18 M $\Omega$; Millipore Direct-QTM). Aerosol particles were generated by nebulizing the solutions using a single jet atomizer (HCT4810) on the Si wafer substrates (MTI Corporation; $99.999 \%$ purity). The size of the droplets examined at $\mathrm{RH}>90 \%$ ranged from 1 to $15 \mu \mathrm{m}$.

\subsection{In situ Raman microspectrometry (RMS) for particles deposited on a Si wafer}

During the hygroscopic measurements, in situ RMS was performed under a controlled RH to observe the hygroscopic behavior, structural changes, and chemical compositional variations in the aerosols generated from the solutions. The apparatus consisted of three parts: (a) see-through impactor, (b) Raman microscope or spectrometer, and (c) humiditycontrolling system. The Si wafer substrate was mounted on the impaction plate in the see-through impactor. A more detailed discussion of the impactor and humidity-controlling system can be found elsewhere (Gupta et al., 2015). Briefly, the $\mathrm{RH}$ inside the impactor was controlled by mixing dry and wet (saturated with water vapor) $\mathrm{N}_{2}(99.999 \%$ purity) gases. The total flow rates of $4 \mathrm{~L} \mathrm{~min}^{-1}$ of the dry and wet $\mathrm{N}_{2}$ gases were controlled by two mass flow controllers to obtain the desired RH in the range of $\sim 1 \%-95 \%$, which was monitored using a digital hygrometer (Testo 645). The digital hygrometer was calibrated using a dew-point hygrometer (M2 Plus-RH, GE) to provide $\mathrm{RH}$ readings with $\pm 0.5 \%$ reproducibility. The Raman spectra and optical images of the aerosol particles were recorded by Labspec6 using a confocal Raman microspectrometer (XploRA, Horiba Jobin Yvon) equipped with a $\times 50,0.5$ numerical aperture objective (Olympus). An excitation laser with a wavelength of $532 \mathrm{~nm}$ and $6 \mathrm{~mW}$ power was used, and the scattered Raman signals were detected at specific RHs during the hygroscopic measurements using an air-cooled multichannel charge-coupled device (CCD) detector. The data acquisition time for each measurement was $120 \mathrm{~s}$. The spectral resolution was $1.8 \mathrm{~cm}^{-1}$ using 1800 grooves $\mathrm{mm}^{-1}$. The optical images were recorded continuously in $\mathrm{RH}=1 \%$ steps with a size of 904 pixels $\times 690$ pixels during the first dehydration (by decreasing $\mathrm{RH}$ from $\sim 95 \%$ to $\sim 1 \%$ ), followed by the humidification (by increasing $\mathrm{RH}$ from $\sim 1 \%$ to $\sim 95 \%$ ) experiments using a top video camera assembled in the Raman instrument and processed using an image analysis software (Matrox, Inspector v9.0). Each humidity condition was sustained for at least $2 \mathrm{~min}$ in order to provide enough time for condensing or evaporating of water. The changes in particle size with the RH were monitored by measuring the particle 2$\mathrm{D}$ area in the optical images to generate hygroscopic curves. These curves are represented by the area ratio $\left(A / A_{0}\right)$ as a function of $\mathrm{RH}$, where the 2-D projected aerosol area at a given $\mathrm{RH}(A)$ is divided by that at the end of the dehydration process $\left(A_{0}\right.$; Ahn et al., 2010). All hygroscopic experiments were conducted at room temperature $\left(T=22 \pm 1^{\circ}\right)$. Aerosol particles generated from a pure- $\mathrm{NaCl}$ aqueous solution to check the accuracy of the system showed typical hysteresis curves with deliquescence RH $(\mathrm{DRH})=75.5( \pm 0.5) \%$ and 
efflorescence RH $($ ERH $)=46.3-47.6 \%$, as shown in Fig. S2 in the Supplement, which are consistent with the theoretical and reported values.

\subsection{SEM-EDX X-ray mapping of effloresced particles deposited on Si wafer}

SEM-EDX X-ray mapping was performed for effloresced particles to determine the morphology and spatial distribution of the chemical elements after the hygroscopicity measurements of individual particles (Ahn et al., 2010; Gupta et al., 2015). The measurements were carried out using a Jeol JSM-6390 scanning electron microscope equipped with an Oxford Link super atmospheric thin window (SATW) EDX detector. The resolution of the detector was $133 \mathrm{eV}$ for $\mathrm{Mn}$ $\mathrm{K} \alpha \mathrm{X}$-rays. The X-ray spectra and elemental X-ray maps were recorded under the control of Oxford INCA Energy software. A $10 \mathrm{kV}$ accelerating voltage and $0.7 \mathrm{nA}$ beam current were used, and the typical measuring time for the elemental mapping was $5 \mathrm{~min}$. An elemental quantification procedure, which is well described elsewhere (Wu et al., 2019a), was used for obtaining the elemental concentration.

\subsection{In situ RMS assembled with a levitation system}

The levitation experimental setup consisted of coupling an acoustic (ultrasonic) levitator equipped with an environmental cell to an RMS, as shown in Fig. S1. The theory of acoustic levitation is described in detail elsewhere (Seaver et al., 1989). An ultrasonic levitator was modified (APOS BA 10, Tec5, Germany) to be installed within an environmental levitation cell consisting of two quartz windows, allowing the particle analysis (Seng et al., 2018). Two inlet/outlet valves were used for gas supplies to modify the relative humidity (RH) inside the cell. A sensor (SHT75 Sensirion) was placed in the cell to control the RH and temperature. The RH inside the chamber was controlled by mixing dry and wet $\mathrm{Ar}$ gases with a flow rate of $200 \mathrm{~mL} \mathrm{~min}^{-1}$ in the range of $10 \%-$ $80 \%( \pm 1 \%) \mathrm{RH}$, and the temperature was $T=25 \pm 3{ }^{\circ} \mathrm{C}$, making the experiments close to static-flow conditions. The control of humidity and temperature allows limited droplet evaporation and long-term monitoring of the particles. The RMS measurements were performed with a LabRAM HR Evolution confocal spectrometer (Horiba Scientific, S.A) at certain RHs first during humidification and then during dehydration. The instrument was equipped with a $\times 50,0.45$ numerical aperture Olympus objective (working distance, $\mathrm{WD}=13.8 \mathrm{~mm})$ and a He-Ne laser $(\lambda=632.8 \mathrm{~nm}, 6 \mathrm{~mW})$ with a theoretical lateral resolution of $\sim 2 \mu \mathrm{m}$ and a depth of the laser focus corresponding to $16 \mu \mathrm{m}$ with a $\Delta z$ limit $\geq \pm 3 \mu \mathrm{m}$. The cell was mounted on an XYZ stage under the objective, allowing an adjustment of the droplet to the optimal position for the measurements. The mean size of the initial droplet injected in the levitator was $80 \mu \mathrm{m}$. The Raman

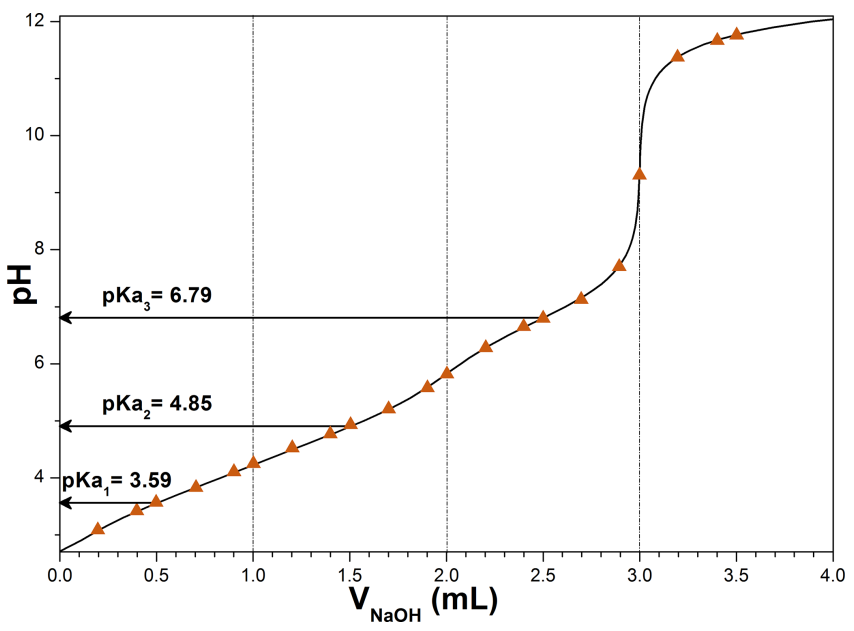

Figure 1. Calculated titration curve for MBTCA, noted as $\mathrm{H}_{3} \mathrm{M}$ in this figure. The experimental data are shown as orange triangles. A total of $5 \mathrm{~mL}$ of $0.02 \mathrm{M} \mathrm{H}_{3} \mathrm{M}$ was titrated with a $0.1 \mathrm{M} \mathrm{NaOH}$ solution.

spectra and optical images recorded at specific RHs were analyzed similarly to those obtained on the Si wafer.

\subsection{Measurement of acid dissociation constants of MBTCA}

MBTCA is a tricarboxylic acid with three acid dissociation constants. To determine the three constants, a $0.02 \mathrm{M}$, $5 \mathrm{~mL}$ MBTCA solution was titrated with a $0.1 \mathrm{M} \mathrm{NaOH}$ solution, where the constants were determined based on the Henderson-Hasselbalch equations (Harris, 2012):

$$
\begin{gathered}
\mathrm{H}_{3} \mathrm{M}+\mathrm{OH}^{-} \rightarrow \mathrm{H}_{2} \mathrm{M}^{-}+\mathrm{H}_{2} \mathrm{O} \\
\mathrm{pH}=\mathrm{pKa}_{1}+\log \left(\left[\mathrm{H}_{2} \mathrm{M}^{-}\right] /\left[\mathrm{H}_{3} \mathrm{M}\right]\right) \\
\mathrm{H}_{2} \mathrm{M}^{-}+\mathrm{OH}^{-} \rightarrow \mathrm{HM}^{2-}+\mathrm{H}_{2} \mathrm{O} \\
\mathrm{pH}=\mathrm{pKa}_{2}+\log \left(\left[\mathrm{HM}^{2-}\right] /\left[\mathrm{H}_{2} \mathrm{M}^{-}\right]\right) \\
\mathrm{HM}^{2-}+\mathrm{OH}^{-} \rightarrow \mathrm{M}^{3-}+\mathrm{H}_{2} \mathrm{O} \\
\mathrm{pH}=\mathrm{pKa}_{3}+\log \left(\left[\mathrm{M}^{3-}\right] /\left[\mathrm{HM}^{2-}\right]\right),
\end{gathered}
$$

where $\mathrm{H}_{3} \mathrm{M}, \mathrm{H}_{2} \mathrm{M}^{-}, \mathrm{HM}^{2-}$, and $\mathrm{M}^{3-}$ represent aqueous MBTCA and mono-, di-, and trisodium MBTCA anions, respectively. The $\mathrm{pKa}_{1}, \mathrm{pKa}_{2}$, and $\mathrm{pKa}_{3}$ are the $\mathrm{pHs}$ when $\left[\mathrm{H}_{3} \mathrm{M}\right],\left[\mathrm{H}_{2} \mathrm{M}^{-}\right]$, and $\left[\mathrm{HM}^{2-}\right]$ equal $\left[\mathrm{H}_{2} \mathrm{M}^{-}\right],\left[\mathrm{HM}^{2-}\right]$, and $\left[\mathrm{M}^{3-}\right]$, respectively, during the acid-base titration. Specifically, when $\mathrm{NaOH}$ was added at $0.5,1.5$, and $2.5 \mathrm{~mL}$, the corresponding $\mathrm{pHs}$ of the solution are the three constants, which were $3.59,4.85$, and 6.79 . Figure 1 shows the calculated titration curve of MBTCA using the three determined Ka values, which is the same as the experimentally obtained titration data, supporting the validity of the Ka values, which were not reported so far. 


\section{Results and discussion}

\subsection{Hygroscopic behavior of pure MBTCA particles}

Wet-deposited MBTCA aerosols generated by the nebulization from a pure MBTCA solution exhibited three different types of hygroscopic behaviors, which are termed types 1,2 , and 3. As shown in Fig. 2, during the dehydration process, the exemplar droplets of types 1 and 2 shrank continuously with decreasing RH due to water evaporation until RHs of $58.4 \%$ and $40 \%$ and then effloresced promptly at $\mathrm{RH}=57.8 \%$ and gradually at $\mathrm{RH}=39 \%-35 \%$, respectively. The effloresced particles maintained their size and shape with further decreases in RH, whereas the type 3 aerosols decreased continuously in size without a distinct change from $\mathrm{RH}=94 \%$ to $\mathrm{RH}=3 \%$ during the dehydration process. During the humidification process, type 1 and 2 particles kept the same size and shape until $\mathrm{RH}=\sim 90 \%$, while type 3 particles experienced a gradual shrinkage at $\mathrm{RH}=34 \%-36.7 \%$ and remained the same until $\mathrm{RH}=\sim 85 \%$. Figure 2 also presents the corresponding optical images and in situ Raman spectra to assess the structural evolution of the MBTCA aerosols during the dehydration and humidification processes. Briefly, Raman peaks at $\sim 1411-1420, \sim 1460$ and $\sim 2950, \sim 1660$ 1730 , and $\sim 3420-3475 \mathrm{~cm}^{-1}$ are for vibrations of $\mathrm{C}=\mathrm{O}$ from $\mathrm{COO}^{-}, \mathrm{CH}, \mathrm{C}=\mathrm{O}$ from $\mathrm{COOH}$, and $\mathrm{OH}$ from water, respectively (Edsall, 1937; An et al., 2016). The redshift of the $\mathrm{C}=\mathrm{O}$ peak (from $\mathrm{COOH}$ ) from 1715 to $1660 \mathrm{~cm}^{-1}$ with decreasing FWHH (full width at half height), which is consistent with the standard MBTCA crystal, and the irregular shape and rough surface of type 1 and 2 aerosols at $\mathrm{RH}=57.8 \%$ and $35 \%$, respectively, confirmed that the particles effloresced into a solid phase. The optical images in the inset above the hygroscopic curve of the type 2 particles showed gradual efflorescence at $\mathrm{RH}=39 \%-35 \%$. The water peak at $\sim 3475 \mathrm{~cm}^{-1}$ disappeared as well after the efflorescence. In contrast, type 3 aerosols maintained a circular morphology until $\mathrm{RH}=3 \%$, as shown in the optical images in Fig. 2, even though an overlapped $\mathrm{C}=\mathrm{O}$ (from $\mathrm{COOH}$ ) peak at $1660-1680 \mathrm{~cm}^{-1}$ appeared during the dehydration process, and the water peak became undetectable, as shown in the Raman spectra at RHs of $45 \%$ and $3 \%$, suggesting an amorphous and solid state as well as the presence of an activation barrier or diffusional resistance to homogeneous nucleation required for the crystallization of MBTCA droplets as efflorescence is a kinetically controlled process (Martin, 2000; Freedman, 2017). Previous studies reported that $\alpha$ pinene SOAs were very likely to exist as a highly viscous semisolid or even glassy state at low humidity (Saukko et al., 2012; Renbaum-Wolff et al., 2013; Berkemeier et al., 2014; Dette et al., 2014; Kidd et al., 2014; Song et al., 2016; Lessmeier et al., 2018). In addition, many organic substances, such as carboxylic acids, carbohydrates, and proteins, tend to form amorphous rather than crystalline phases upon the drying of aqueous-solution droplets (Mikhailov et al., 2009).
During the humidification process, the Raman spectra and morphology remained unchanged for type 1 and 2 particles until $\mathrm{RH}=\sim 90 \%$, where a slight decrease in morphology was observed due to structural rearrangements by the absorption of moisture on the lattice imperfections (Gysel et al., 2002). Besides, the substrate can also affect this shrinkage. The hydrophilic substrate (such as the Si wafer used in this study) especially seems to favor the phenomenon (Eom et al., 2014). Type 3 particles during the humidification process became irregular in shape, and the overlapped $\mathrm{C}=\mathrm{O}$ (from $\mathrm{COOH}$ ) peak shifted to $1660 \mathrm{~cm}^{-1}$ at $\mathrm{RH}=36.7 \%$, as shown in the optical image and Raman spectrum, indicating the formation of solids. With the further increase in $\mathrm{RH}$, particles maintained their size and shape until $\mathrm{RH}=85 \%$, where they started to decrease in size due to a rearrangement in structure. All types of MBTCA particles maintained the crystal phase until $\mathrm{RH}=95 \%$.

Specifically, the types of hygroscopicity of pure MBTCA particles were classified as type 1 (with a prompt efflorescence at $\sim 50 \% \mathrm{RH}$ during dehydration), type 2 (with a gradual efflorescence at $\sim 35 \% \mathrm{RH}$ during dehydration), and type 3 (with a gradual efflorescence at $\sim 37 \%$ RH during humidification) based on their different behavior when efflorescence occurred. The different efflorescence behavior was attributed to different nucleation mechanisms: heterogeneous nucleation for type 1 and 2 particles (seed-containing) and homogeneous nucleation for type 3 particles (pure). MBTCA powders, which were used for making the MBTCA solution, have an intrinsic unknown impurity of $2 \%$, and they were used without any purification. When MBTCA powders were dissolved in DI water, and particles were generated by the nebulization of the aqueous solution using $\mathrm{N}_{2}$ gas, impurities were either absent or associated with the droplets. The impurities existed in type 1 and 2 particles after nebulization, acting as seed crystals to induce efflorescence. Aqueous moieties in particles were reported to effloresce more easily by heterogeneous nucleation in the presence of seeds (Schlenker and Martin, 2005; Li et al., 2014; Gupta et al., 2015). The lower ERH and gradual efflorescence of type 2 compared to type 1 particles might be due to the lower number of impurities. Type 3 particles contain negligible or no seed crystals, and large kinetic barrier and/or diffusional resistance make the formation of the crystal structure difficult owing to the decreasing availability of condensed water during dehydration so that they did not experience any efflorescence. A similar situation was observed for $\mathrm{NH}_{4} \mathrm{NO}_{3}, \mathrm{NaNO}_{3}$, and $\mathrm{NH}_{4} \mathrm{HSO}_{4}$ particles (Lightstone et al., 2000; Hoffman et al., 2004; Gibson et al., 2006; Kim et al., 2012; Jing et al., 2018; Sun et al., 2018; Wu et al., 2019b). The Si substrates used in this study could also facilitate efflorescence (Eom et al., 2014; Wang et al., 2017). The efflorescence during humidification like type 3 particles was previously reported for Amazonian rain forest aerosols (Pöhlker et al., 2014) and the laboratory-generated $\mathrm{NaCl}-\mathrm{MgCl}_{2}$ mixture particles (Gupta et al., 2015). Thus, this phenomenon is not rare, and it was claimed that the 


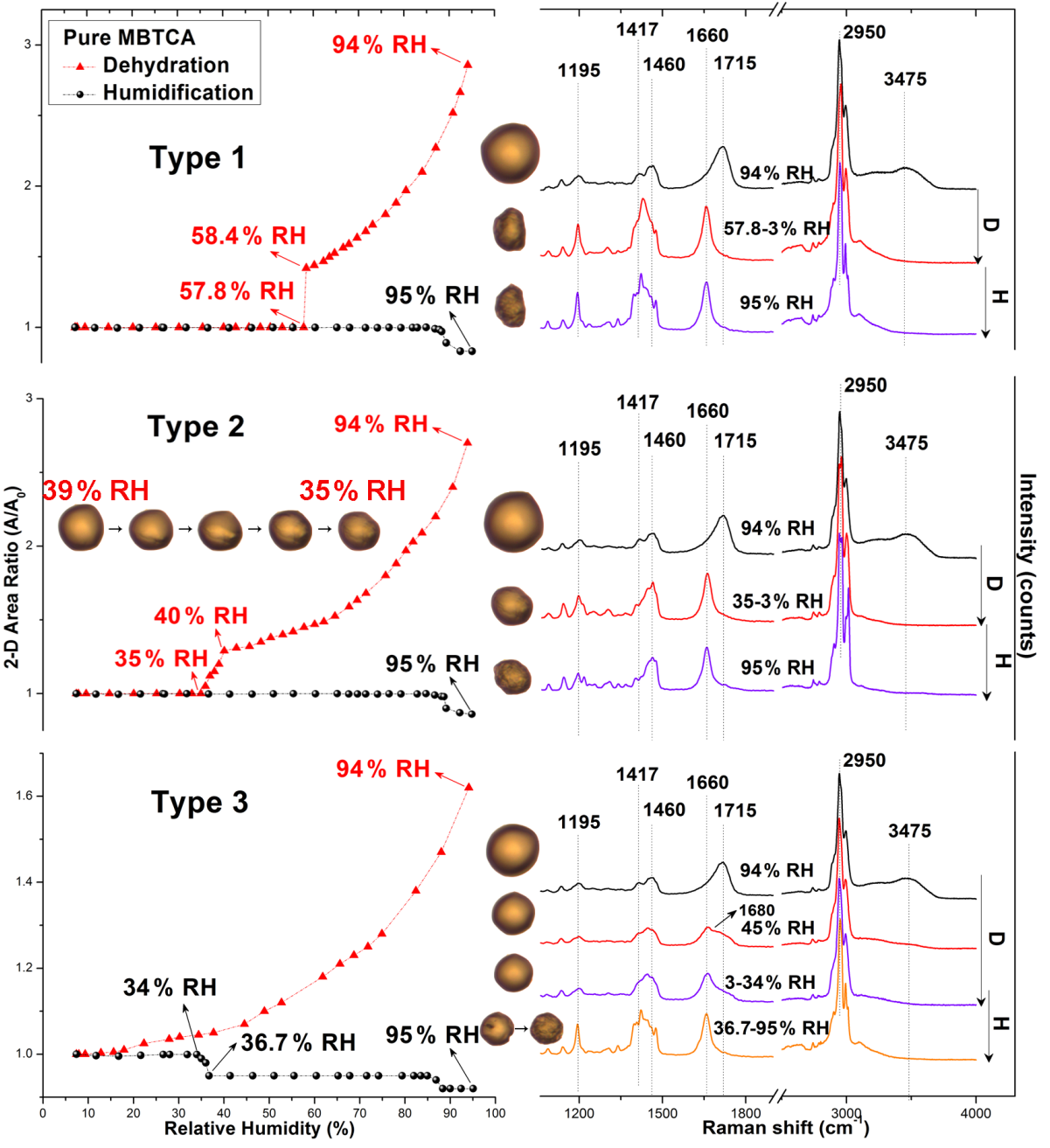

Figure 2. Hygroscopic curves, corresponding optical images, and Raman spectra at specific RHs of three types of pure MBTCA particles. The transition RHs recorded during the dehydration (D) and humidification (H) processes are marked with arrows in the hygroscopic curves.

aerosol particles initially had amorphous or polycrystalline structures and underwent restructuring through kinetic water and ion mobilization in the presence of sufficient condensed water, resulting in overcoming the kinetic barrier and crystallization during humidification.

Among 100 particles, type 1,2 , and 3 particles accounted for approximately $25 \%, 5 \%$, and $70 \%$, respectively, suggesting that MBTCA has a slow homogeneous nucleation rate. Based on the experimental results, MBTCA droplets have $\mathrm{DRH}>95 \%$ and $\mathrm{ERH}=30 \%-58 \%$. This is the first study reporting the hygroscopic properties of MBTCA. A previous study showed that MBTCA was not hydrated significantly in the ambient atmosphere (Kildgaard et al., 2018), and our results also implied that the MBTCA solids stay in the air once they effloresced, based on our results.

\subsection{Hygroscopic behavior of mono-/di-/trisodium MBTCA salt aerosols}

The hygroscopicity and Raman spectra of mono-/di/trisodium MBTCA salt aerosols (hereafter denoted as $\mathrm{NaH}_{2} \mathrm{M}, \mathrm{Na}_{2} \mathrm{HM}$, and $\mathrm{Na}_{3} \mathrm{M}$, respectively) were studied to examine the hygroscopic behavior and estimate the chemical reactivity of MBTCA with $\mathrm{NaCl}$. Figure $3 \mathrm{a}-\mathrm{c}$ show the 2-D projected area ratio plot of aerosol particles generated from $0.3 \mathrm{M} \mathrm{NaH}_{2} \mathrm{M}, \mathrm{Na}_{2} \mathrm{HM}$, and $\mathrm{Na}_{3} \mathrm{M}$ aqueous solutions as a function of the RH together with the corresponding optical images and Raman spectra recorded at specific RHs. As shown in Fig. 3a and b, $\mathrm{NaH}_{2} \mathrm{M}$ and $\mathrm{Na}_{2} \mathrm{HM}$ aerosols shrank and grew continuously without a phase transition during the dehydration and humidification processes, respectively, which is also reflected in the optical images and Raman spectra, where they maintained their circular morphology only with a change in size and the same Raman peak patterns and positions, with small variations in the relative peak intensi- 
ties during the entire process. The water peak at $\sim 3400$ $3500 \mathrm{~cm}^{-1}$ can still be observed at the end of the dehydration process. Even after being kept in a desiccator for 2 months, $\mathrm{NaH}_{2} \mathrm{M}$ and $\mathrm{Na}_{2} \mathrm{HM}$ particles still showed the same shapes and Raman spectra with those at RHs of $3.4 \%$ and $2.8 \%$, respectively. These results indicate the noncrystallizable properties and supersaturated amorphous phase state of the particles. The $\mathrm{Na}_{3} \mathrm{M}$ particles behaved differently as they did not crystallize during the dehydration process. On the other hand, the aerosols exhibited efflorescence at $\mathrm{RH}=46.8 \%$ during the humidification process (Fig. 3c), deliquesced to become a droplet at $\mathrm{RH}=53.1 \%$, and grew continuously after that with increasing RH. The Raman spectra of the $\mathrm{Na}_{3} \mathrm{M}$ particles in Fig. 3c showed that the peak at $1420-1460 \mathrm{~cm}^{-1}$ became two sharp peaks when the particles effloresced, and the $\mathrm{OH}$ peak at $3400 \mathrm{~cm}^{-1}$ indicates that $\mathrm{Na}_{3} \mathrm{M}$ particles possibly exist in the hydrated form. The $\mathrm{Na}_{3} \mathrm{M}$ particles behaved analogously to type 3 MBTCA particles, which might be due to their similar structures when all three $\mathrm{COOH}$ in MBTCA were replaced with COONa upon the reaction between MBTCA and $\mathrm{NaOH}$. Since all the observed $\mathrm{Na}_{3} \mathrm{M}$ particles on the substrate (around 100 particles) behaved exactly in the same way with crystallization during the humidification process, the major contribution to the crystallization of $\mathrm{Na}_{3} \mathrm{M}$ particles is homogeneous crystallization instead of heterogeneous crystallization induced by impurities and the Si substrate effect. Based on the top Raman spectra of aqueous MBTCA, $\mathrm{NaH}_{2} \mathrm{M}, \mathrm{Na}_{2} \mathrm{HM}$, and $\mathrm{Na}_{3} \mathrm{M}$ aerosols in Figs. 2 and 3, the ratios of the $\mathrm{CH}$ peak at $\sim 1460 \mathrm{~cm}^{-1}$ to the $\mathrm{C}=\mathrm{O}$ peak at $\sim 1720 \mathrm{~cm}^{-1}$ (from $\mathrm{COOH}$ ) and to the $\mathrm{C}=\mathrm{O}$ peak at $\sim 1420 \mathrm{~cm}^{-1}$ (from $\mathrm{COO}^{-}$) increased and decreased in the order of MBTCA, $\mathrm{NaH}_{2} \mathrm{M}, \mathrm{Na}_{2} \mathrm{HM}$, and $\mathrm{Na}_{3} \mathrm{M}$ because of their reduced and elevated levels of $\mathrm{COOH}$ and $\mathrm{COO}^{-}$, respectively.

\subsection{Hygroscopic behavior of MBTCA-NaCl mixture aerosols}

Aerosols were generated by the nebulization of MBTCA$\mathrm{NaCl}$ mixture solutions of molar mixing ratios of MBTCA $: \mathrm{NaCl}=1: 1,1: 2,1: 3$, and $2: 1$ and deposited on Si wafer substrates while maintaining the entire hygroscopic measurement system at $\mathrm{RH}>90 \%$. The hygroscopic behavior was investigated for $\sim 10$ individual aerosols of each mixing ratio, which are discussed in the following sections.

\subsubsection{Aerosols generated from solutions of MBTCA $: \mathrm{NaCl}=1: 1$ and $2: 1$}

Figure 4 presents the hygroscopic curves of representative aerosols nebulized from solutions of MBTCA : $\mathrm{NaCl}$ mixtures at different molar ratios (1:1 and 2:1) along with the corresponding optical images and Raman spectra at specific RHs. During the dehydration process, the circular liquid droplets decreased in size gradually without any noticeable phase change. The Raman peak patterns were maintained only with the $\mathrm{C}=\mathrm{O}$ peak at $1721 \mathrm{~cm}^{-1}$ (from $\mathrm{COOH}$ ) shifting mildly rightwards; the water peak at $3466 \mathrm{~cm}^{-1}$ becoming undetectable; and the relative peak intensities at $\sim 1411$, 1457 , and $1721 \mathrm{~cm}^{-1}$ varying when the RH was as low as $1.2 \%$, indicating that the liquid droplets formed amorphous solids. The peak at $1680 \mathrm{~cm}^{-1}$ on the Raman spectra of MBTCA : $\mathrm{NaCl}=2: 1$ at $\mathrm{RH}=1.2 \%$ suggested that the amorphous structure of the remaining MBTCA had been retained. Both MBTCA and $\mathrm{NaCl}$ have their DRHs and ERHs. Therefore, a stepwise efflorescence would happen if it is assumed that the mixture aerosols are an MBTCA-NaCl binary system, i.e., a component of the aqueous droplets precipitates first at their specific ERHs depending on their mixing ratios, and the second crystallization from the remnant eutonic solution occurs at their mutual ERH (MERH) with further decreases in RH, which is independent of the mixing ratios, generally forming a heterogeneous, core-shell crystal structure owing to the two-stage crystallization process (Ge et al., 1996; Gupta et al., 2015). However, the particles of MBTCA $: \mathrm{NaCl}=1: 1$ and $2: 1$ mixing ratios did not follow the stepwise transitions in the present study, revealing that the aerosols do not belong to the MBTCA-NaCl binary system, and the chemical compositions evolved during the hygroscopic experiment due to the reaction between MBTCA and $\mathrm{NaCl}$, which is discussed later.

During the humidification process, aerosol particles of two mixing ratios grew continuously when the $\mathrm{RH}$ was increased from $1.2 \%$ to $90 \%$, with the $\mathrm{C}=\mathrm{O}$ peak (from $\mathrm{COOH}$ ) shifting back to $\sim 1721 \mathrm{~cm}^{-1}$ and the water peak becoming significant, as shown in Fig. 4. Several small crystal-like spots, which are marked by a dotted circle on the inset optical image beside the hygroscopic curve in Fig. 4a, appeared in the particles with the mixing ratio of MBTCA $: \mathrm{NaCl}=1: 1$ when the RH was increased to $67.2 \%$ and dissolved completely at $\mathrm{RH}=71.2 \%$. As the Raman spectra did not show any signals of the crystallized organics, and $\mathrm{RH}=71.2 \%$ is close to the DRH of pure $\mathrm{NaCl}(75( \pm 0.5) \%)$, the crystallike moieties should result from the effloresced $\mathrm{NaCl}$. The more noticeable water peak in the Raman spectrum taken at $\mathrm{RH}=71.2 \%$ than that at $\mathrm{RH}=67.2 \%$ also supports the fact that the $\mathrm{NaCl}$ dissolved at $\mathrm{RH}=71.2 \%$ as $\mathrm{NaCl}$ is quite hygroscopic ( $\mathrm{Li}$ et al., 2017). No phase transition of $\mathrm{NaCl}$ was detected during the dehydration process, probably because the supersaturated organic moiety inhibited the crystallization of $\mathrm{NaCl}$. The observation of effloresced particles during the humidification process might be caused by the structural rearrangement of the amorphous particles upon the slow and continuous absorption of moisture with increasing RH (Mikhailov et al., 2009), leading to less restriction to $\mathrm{NaCl}$ crystallization. Indeed, organics in organic-inorganicmixture aerosols were reported to be a minor disturbance to the DRH of inorganic salts; in contrast, they may markedly decrease the ERH of inorganic salts depending on the organic type (Parsons et al., 2004). 

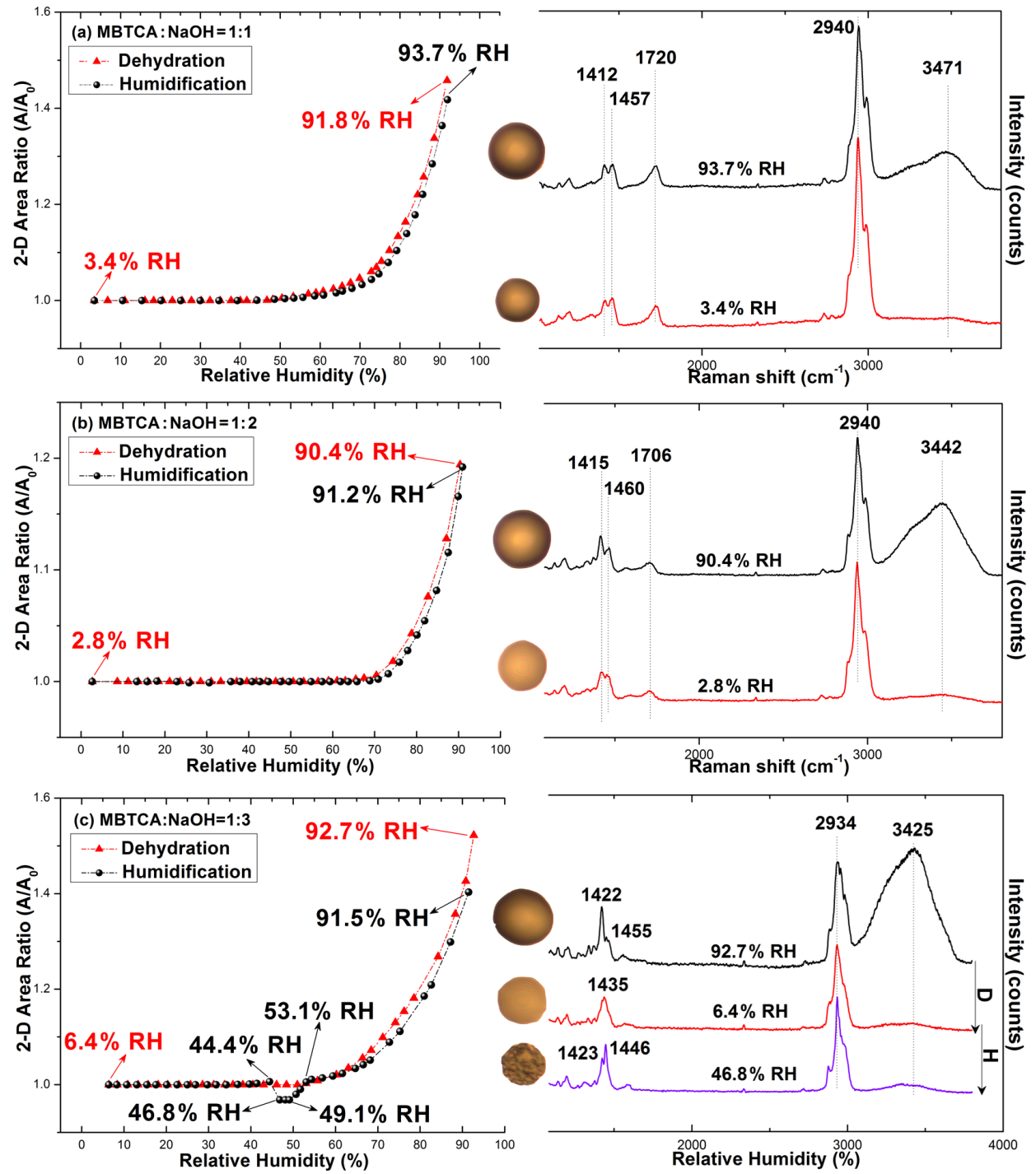

Figure 3. Hygroscopic curves, corresponding optical images, and Raman spectra at specific RHs of (a) mono-, (b) di-, and (c) trisodium MBTCA salt aerosols. The recorded transition RHs during the dehydration and humidification processes are marked with arrows in the hygroscopic curves.

\subsubsection{Aerosols generated from solutions of MBTCA $: \mathrm{NaCl}=1: 2$ and $1: 3$}

Figure 5 shows the hygroscopic curves of aerosol particles nebulized from solutions of MBTCA : $\mathrm{NaCl}$ with molar mixing ratios of $1: 2$ and $1: 3$ together with the corresponding optical images and Raman spectra at the transition RHs. During the dehydration process, droplets from the solutions of MBTCA $: \mathrm{NaCl}=1: 2$ and $1: 3$ decreased gradually in size owing to water evaporation until a single-stage transition was observed at RHs of $47.2 \%-46.5 \%$ and $46.7 \%-45.8 \%$, respectively, where the particle shape became less circular in the optical images. At this point, the following was observed in the Raman spectra: the water peak at $3455 \mathrm{~cm}^{-1}$ disappeared; the $\mathrm{C}=\mathrm{O}$ peak at $\sim 1722$ and $1720 \mathrm{~cm}^{-1}$ (from
$\mathrm{COOH})$ shifted slightly rightwards; the relative peak intensities at 1417 and 1416, 1461, and 1722 and $1720 \mathrm{~cm}^{-1}$ varied. With the further decreases in RH until $\sim 6 \%$, the particles kept their size and shape. During the humidification process, all particles of MBTCA: $\mathrm{NaCl}=1: 2$ and $1: 3$ maintained their structure until RHs of $50 \%$ and $40 \%$, respectively, where they experienced a size decrease due to structural rearrangement until $\mathrm{RH}=\sim 70 \%$; grew continuously to become circular at $\mathrm{RH}=\sim 73 \%$; and totally deliquesced into homogeneous droplets at RHs of $73.9 \%$ and $74.5 \%$, respectively. Particle size and water peak increased rapidly, and the $\mathrm{C}=\mathrm{O}$ peak $(\mathrm{COOH})$ shifted back to $1720 \mathrm{~cm}^{-1}$. Upon a further increase in RH, they grew continuously by water absorption. The ERH and DRH were attributed to the $\mathrm{NaCl}$ moiety as the Raman spectra maintained the peak patterns during the 

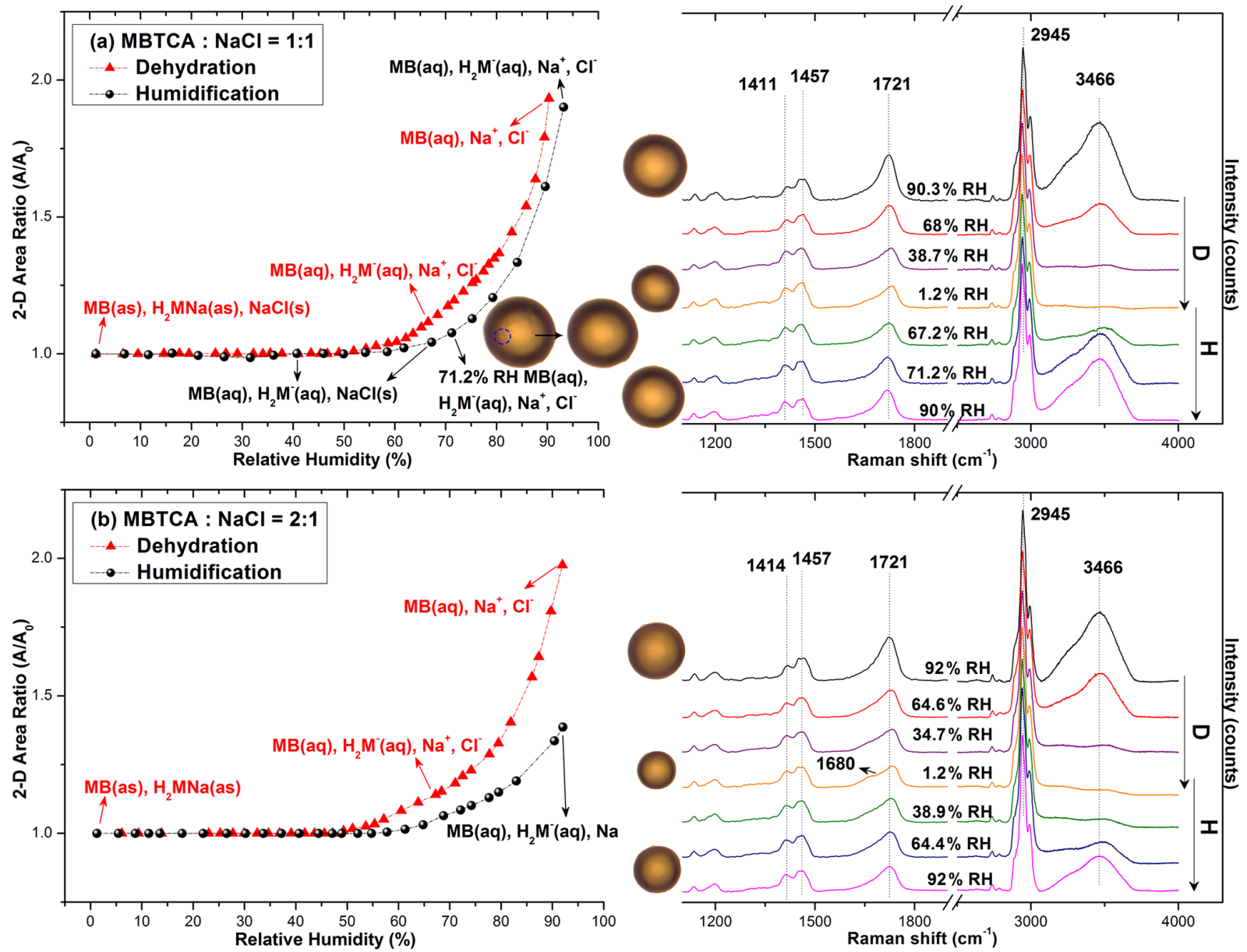

Figure 4. Hygroscopic curves, corresponding optical images, and Raman spectra at specific RHs of MBTCA: $\mathrm{NaCl}=(\mathbf{a}) 1: 1$ and (b) $2: 1$. The recorded transition RHs during the dehydration (D) and humidification (H) processes and the chemical compositions of the mixtures at certain RHs are marked with arrows in the hygroscopic curves. The phase notations shown in parentheses are s - solid, aq - aqueous, and as - amorphous solid.

entire process, and the organic components condensed onto the $\mathrm{NaCl}$ crystal core almost simultaneously as an amorphous shell when efflorescence occurred, which is also indicated by the optical images. Before the complete deliquescence of the $\mathrm{NaCl}$ crystal core, the water peak at $\sim 3455 \mathrm{~cm}^{-1}$ in the Raman spectra and the optical images at $\mathrm{RH}=72.4 \%$ and $73.8 \%$ of the particles from the MBTCA $: \mathrm{NaCl}=1: 2$ and $1: 3$ solutions show that the organic shell was in the liquid phase, meaning that the mixture particles were in a solidliquid equilibrium state (Sun et al., 2018). The Raman spectra shown in the figures were all obtained in the center of the particles. The Raman spectra were obtained at both the center and the edge of the particles for comparison during the measurement when the heterogeneity appeared during the hygroscopic measurements. The spectra from the center and the edge were different only in the intensity since $\mathrm{NaCl}$ is Raman inactive. As shown in Fig. S3, the Raman spectra, which were obtained from the center and the edge of an exemplar MBTCA : $\mathrm{NaCl}=1: 3$ particle during the humidifica- tion process, match well after normalization to the $\mathrm{CH}$ peak at $1460 \mathrm{~cm}^{-1}$.

All the particles from MBTCA : $\mathrm{NaCl}=1: 2$ and $1: 3$ solutions showed hysteresis curves with ERHs in the range of $46.7 \%-45.2 \%$ and $47.2 \%-45.6 \%$, respectively, and DRHs of $73.9( \pm 0.3) \%$ and $74.5( \pm 0.3) \%$, respectively.

\subsubsection{Chemical reactivity of aerosols generated from MBTCA-NaCl mixture solutions}

The first Raman spectra of the aerosols generated from MBTCA- $\mathrm{NaCl}$ mixture solutions in Figs. 4 and 5 were obtained before the dehydration process and are comparable to that of pure MBTCA droplet particles in Fig. 2 except for a much stronger free water peak at $3450-3470 \mathrm{~cm}^{-1}$ due to the presence of a more hygroscopic $\mathrm{NaCl}$ moiety. This suggests that upon nebulization from the solutions, the mixture droplets were mostly the MBTCA-NaCl binary system. The Raman spectra obtained at the beginning of the 

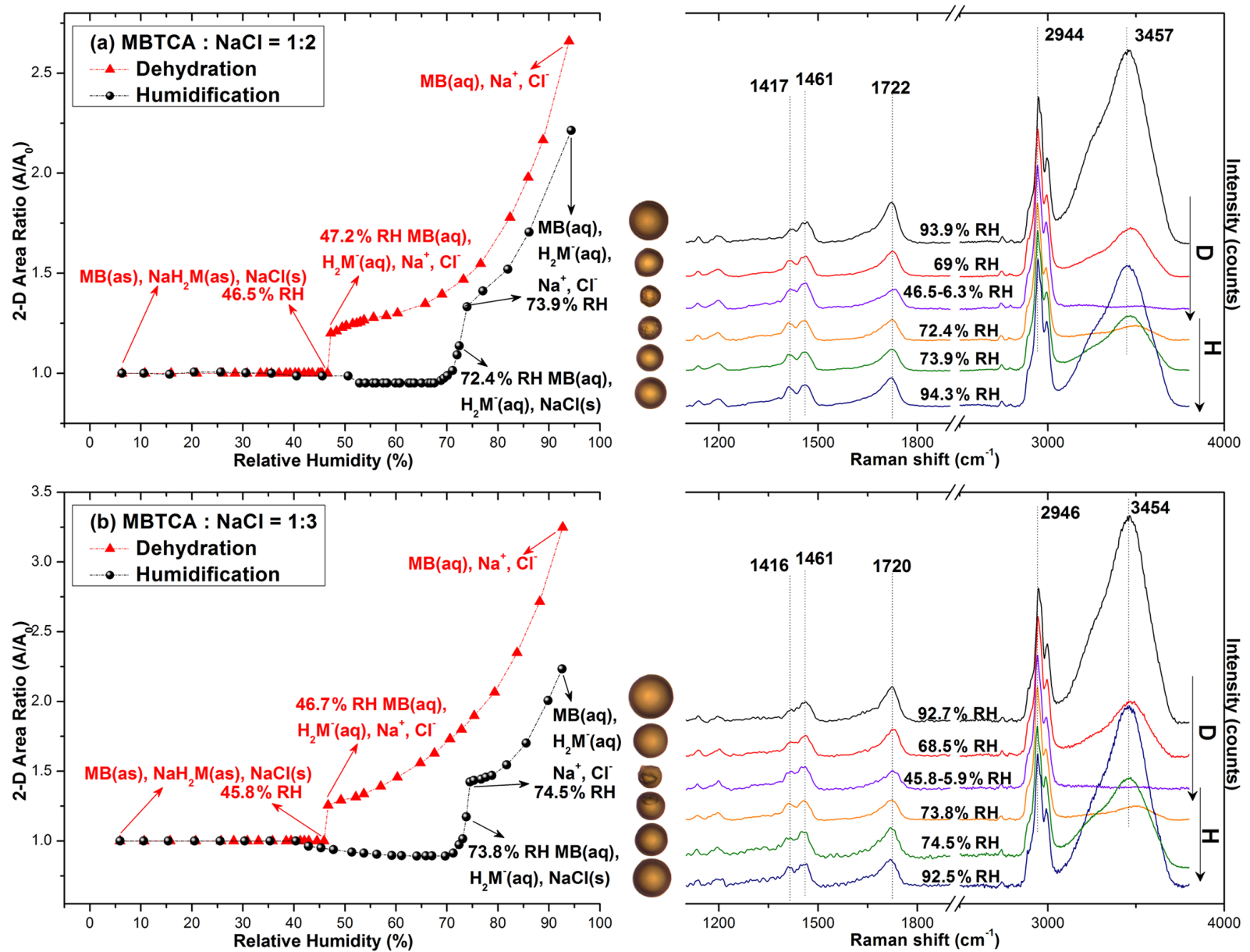

Figure 5. Hygroscopic curves, corresponding optical images, and Raman spectra at specific RHs of MBTCA: $\mathrm{NaCl}=(\mathbf{a}) 1: 2$ and (b) $1: 3$. The recorded transition RHs during the dehydration (D) and humidification (H) processes and the chemical compositions of the mixtures at certain RHs are marked with arrows in the hygroscopic curves. The phase notations shown in parentheses are s - solid, aq - aqueous, and as - amorphous solid.

dehydration process and the end of the humidification process revealed increased and decreased ratios of the $\mathrm{CH}$ peak at $\sim 1460 \mathrm{~cm}^{-1}$ to the $\mathrm{C}=\mathrm{O}$ peaks at $\sim 1720 \mathrm{~cm}^{-1}$ (from $\mathrm{COOH}$ ) and $\sim 1412 \mathrm{~cm}^{-1}$ (from $\mathrm{COO}^{-}$), respectively, which implies that the reaction between MBTCA and $\mathrm{NaCl}$ occurred during the hygroscopic experiment, leading to the decreased and increased levels of the $\mathrm{COOH}$ and $\mathrm{COO}^{-}$moieties, respectively. It is worth noting that the dehydration and humidification curves of the MBTCA-NaCl mixtures did not overlap with each other mainly because of the different amounts of $\mathrm{NaCl}$ in the dehydration and humidification processes. As shown in Fig. S2, NaCl is quite hygroscopic, with around 4 times change in 2-D area after deliquescence, so the decreased amount of $\mathrm{NaCl}$ in the mixtures also leads to the smaller 2-D area when the MBTCA-NaCl mixture particles experienced hygroscopic growth during the humidification process compared to those before dehydration. Figure 6a presents the Raman spectra of particles generated from MBTCA $: \mathrm{NaCl}=1: 1,1: 2$, and $1: 3$ solutions together with that of $\mathrm{NaH}_{2} \mathrm{M}$ particles obtained at the end of humidification by normalizing to the $\mathrm{CH}$ peak at $1458 \mathrm{~cm}^{-1}$. The $\mathrm{C}=\mathrm{O}$ peak intensities at $1720 \mathrm{~cm}^{-1}$ (from $\mathrm{COOH}$ ) and $1412 \mathrm{~cm}^{-1}$ (from $\mathrm{COO}^{-}$) of the particles generated from the mixture solutions were higher and lower, respectively, than those of the $\mathrm{NaH}_{2} \mathrm{M}$ particle, suggesting that the aerosols generated from the MBTCA- $\mathrm{NaCl}$ solutions produced only $\mathrm{NaH}_{2} \mathrm{M}$ as the reaction product between MBTCA and $\mathrm{NaCl}$, regardless of the mixing ratios. The droplet particles after the humidification process were present as an MBTCA-NaCl$\mathrm{NaH}_{2} \mathrm{M}$ ternary system with varying compositions. As the first acid dissociation constant of MBTCA $\left(\mathrm{pKa}_{1}=3.59\right)$ is more than 1 and 3 orders of magnitude larger than the second $\left(\mathrm{pKa}_{2}=4.85\right)$ and third $\left(\mathrm{pKa}_{3}=6.79\right)$, respectively, $\mathrm{H}_{2} \mathrm{M}^{-}$ is more abundant than $\mathrm{HM}^{2-}$ and $\mathrm{M}^{3-}$. The chemical reaction between $\mathrm{NaCl}$ and MBTCA would occur in the aqueous 
phase as follows:

$$
\begin{aligned}
& \operatorname{MBTCA}(\mathrm{aq})+\mathrm{H}_{2} \mathrm{M}^{-}(\mathrm{aq})+\mathrm{H}^{+}(\mathrm{aq})+\mathrm{Na}^{+}(\mathrm{aq}) \\
& +\mathrm{Cl}^{-}(\mathrm{aq}) \rightarrow \mathrm{MBTCA}(\mathrm{aq})+\mathrm{H}_{2} \mathrm{M}^{-}(\mathrm{aq})+\mathrm{Na}^{+}(\mathrm{aq}) \\
& +\mathrm{Cl}^{-}(\mathrm{aq})+\mathrm{HCl}(\mathrm{g}) \uparrow \rightarrow \mathrm{NaH}_{2} \mathrm{M} \\
& (+\mathrm{MBTCA}, \text { amorphous }) \\
& +\mathrm{NaCl}(\mathrm{s}) \text { after the efflorescence. }
\end{aligned}
$$

The $\mathrm{NaH}_{2} \mathrm{M}$ particles may exist as amorphous particles, as described before in Sect. 3.2. Raman spectra of standard aerosols generated from solutions of MBTCA : $\mathrm{NaH}_{2} \mathrm{M}=0: 1,1: 1$, and 1:0 were obtained at different RHs to estimate the chemical reactivity of the aerosol particles generated from the $\mathrm{MBTCA}-\mathrm{NaCl}$ mixture solutions, which were used as a calibration curve to help determine the relative MBTCA and $\mathrm{NaH}_{2} \mathrm{M}$ contents in the aerosols at specific RHs. The estimation of the chemical reactivity between malonic acid and $\mathrm{NaCl}$ performed in a similar way was reported in a previous study (Li et al., 2017). The Raman spectra of $\mathrm{MBTCA}, \mathrm{NaH}_{2} \mathrm{M}$, and mixture aerosols of MBTCA : $\mathrm{NaH}_{2} \mathrm{M}=1: 1$ obtained at $\mathrm{RH}=90 \%$ and normalized to the $\mathrm{CH}_{3}$ peak at $1460 \mathrm{~cm}^{-1}$ showed that the intensity ratio of the two peaks at $1460 \mathrm{~cm}^{-1}\left(\mathrm{CH}_{3}\right)$ and $\sim 1720 \mathrm{~cm}^{-1}\left(\mathrm{C}=\mathrm{O}\right.$ from $\mathrm{COOH}$; i.e., $\left.\mathrm{I}_{1460} / \mathrm{I}_{1720}\right)$ increased with increasing $\mathrm{NaH}_{2} \mathrm{M}$ level because of the decreased $\mathrm{COOH}$ content, as shown in Fig. 6b. The ratio $\mathrm{I}_{1460} / \mathrm{I}_{1720}$ for each standard aerosol exhibited good linearity as a function of RH, as shown in Fig. 7a, where the mean values obtained from 10 aerosols of each standard aerosol sample are plotted with error bars. The Raman intensity ratios of the standard aerosols increased with decreasing RH because the $\mathrm{C}=\mathrm{O}$ stretching vibrations of the free $\mathrm{COOH}$ group in the aqueous phase and the intramolecular hydrogenbonded $\mathrm{COOH}$ group in the supersaturated phase become weaker and stronger (Bertran et al., 2010), respectively, with decreasing $\mathrm{RH}$ during the dehydration process.

The dependency of the $\mathrm{I}_{1460} / \mathrm{I}_{1720}$ ratios on $\mathrm{RH}$ can be used to estimate the MBTCA and $\mathrm{NaH}_{2} \mathrm{M}$ (monosodium MBTCA salt) contents in the NaCl-MBTCA aerosols at specific RHs based on the calibration curve and to calculate the further reactivity. The chemical reactivity of the mixtures is represented as the degree of the reaction, which is defined as the ratio of the consumed amount to the original amount of the limiting reactant. For example, for aerosols from solutions of MBTCA : $\mathrm{NaCl}=2: 1$ and $1: 2, \mathrm{NaCl}$, and MBTCA are the limiting reactants, respectively. Figure $7 \mathrm{~b}$ shows the degree of the reaction of aerosols generated from solutions of each mixing ratio, where the mean degree of reaction has $\sim 1.5 \%-4 \%$ deviations owing to statistical variations in the Raman peak intensities caused by the baseline correction procedure and the uncertainties involved in the calibration measurements. The reactivity was estimated at five stages during one hygroscopic experiment cycle.
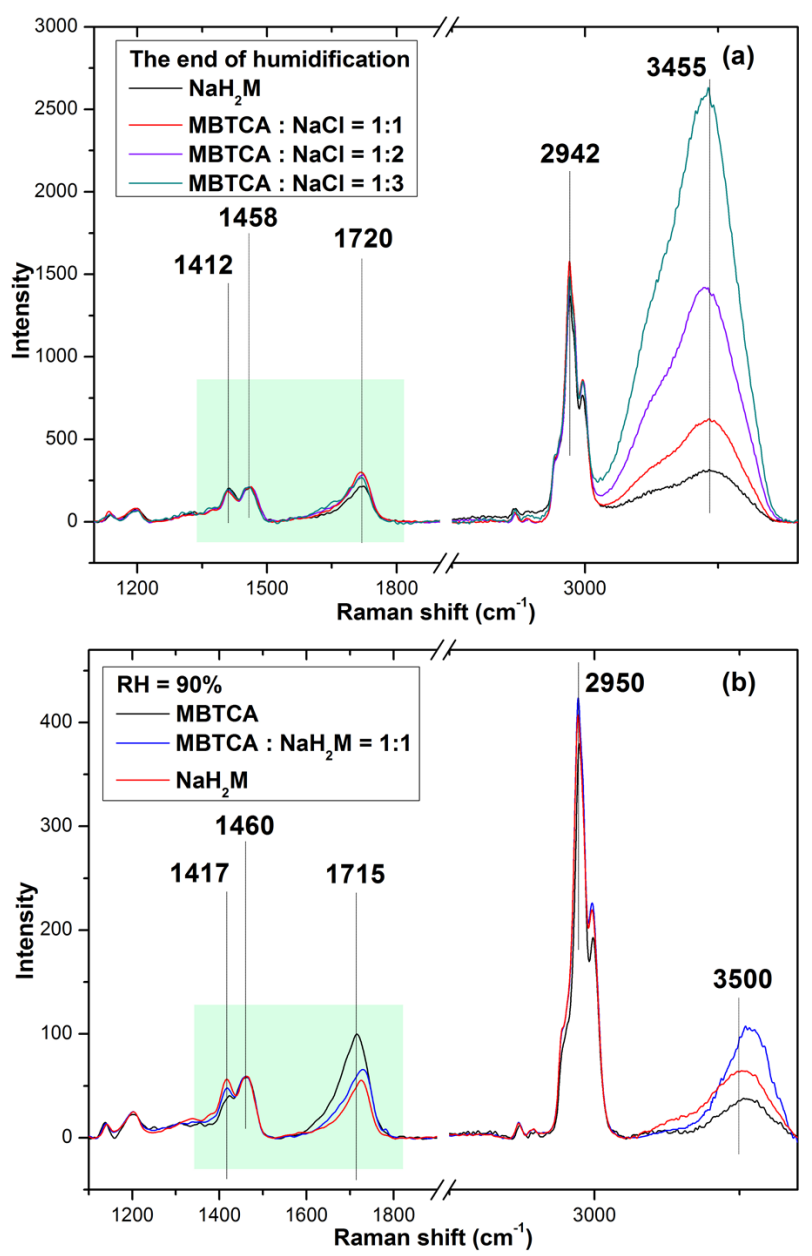

Figure 6. (a) Raman spectra of pure $\mathrm{NaH}_{2} \mathrm{M}$ and mixture aerosols with mixing ratios of MBTCA $: \mathrm{NaCl}=1: 1,1: 2$, and $1: 3$ obtained at the end of the humidification process, which were normalized to the $\mathrm{CH}_{3}$ peak at $1458 \mathrm{~cm}^{-1}$, and (b) Raman spectra of pure MBTCA, mixture of MBTCA : $\mathrm{NaH}_{2} \mathrm{M}=1: 1$, and pure $\mathrm{NaH}_{2} \mathrm{M}$, which are normalized to the $\mathrm{CH}_{3}$ peak at $1460 \mathrm{~cm}^{-1}$.

- Stage 1. At the beginning of the hygroscopic experiment, no reaction occurred for all the mixed droplets based on their Raman spectra; i.e., the degree of the reaction is 0 .

- Stage 2. As the RH decreased during the dehydration process, the reaction continued in the aqueous aerosols until efflorescence of the droplets with mixing ratios of MBTCA : $\mathrm{NaCl}=1: 2$ and $1: 3$ had occurred and until the water content of the aerosols with mixing ratios of MBTCA : $\mathrm{NaCl}=1: 1$ and $2: 1$ became insignificant. The degrees of the reaction of aerosols with mixing ratios of $1: 1,1: 2$, and $1: 3$ were approximately $30 \%$, whereas that of $2: 1$ approached $85 \%$.

- Stage 3. The reaction of aerosols generated from the solution of a mixing ratio of $\mathrm{MBTCA}: \mathrm{NaCl}=2: 1$ was 

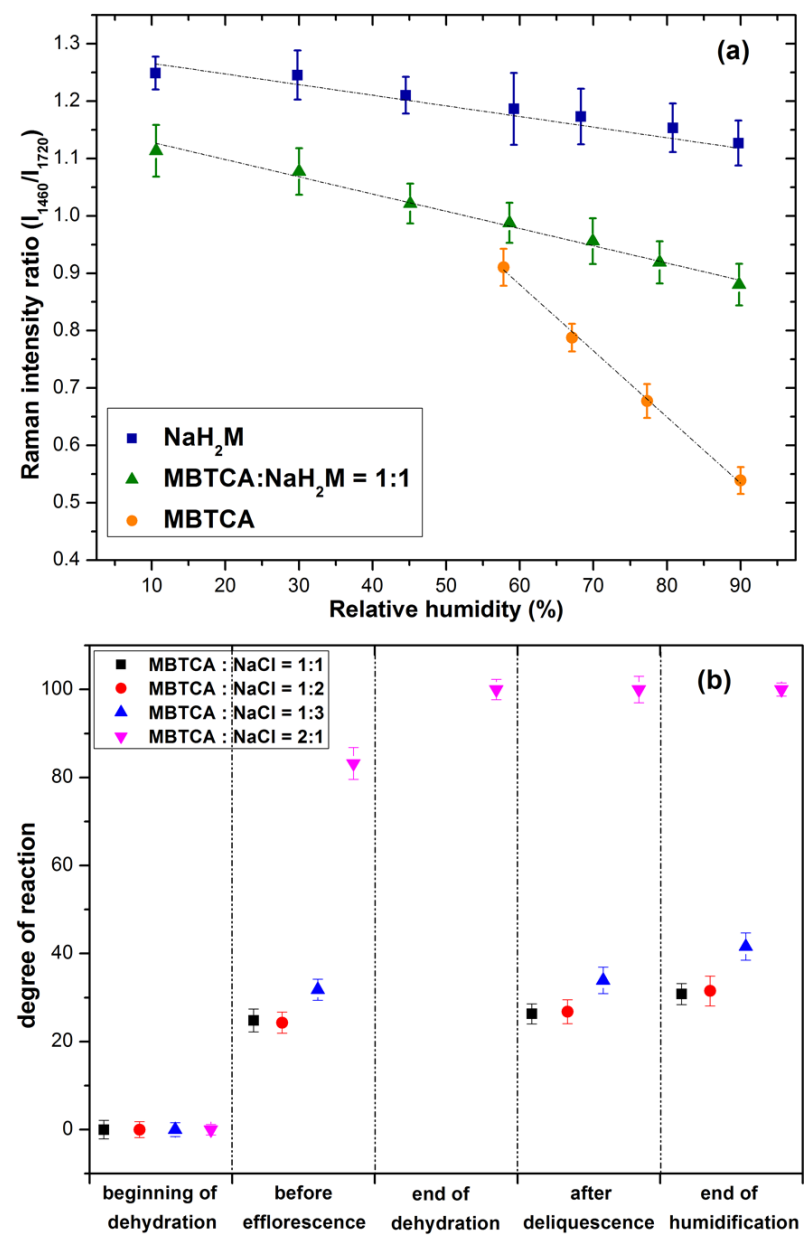

Figure 7. (a) Calibration curve calculated from the intensity ratios of two peaks at 1460 and $1720 \mathrm{~cm}^{-1}$ as a function of RH for $\mathrm{NaH}_{2} \mathrm{M}, \mathrm{MBTCA}: \mathrm{NaH}_{2} \mathrm{M}=1: 1$, and MBTCA aerosols; (b) chemical reactivity represented as the degree of reaction for mixture aerosols of MBTCA : $\mathrm{NaCl}=1: 1,1: 2,1: 3$, and $2: 1$ during the dehydration and humidification processes.

complete at the end of the dehydration process, indicating the total consumption of $\mathrm{NaCl}$ and the formation of an MBTCA: $\mathrm{NaH}_{2} \mathrm{M}=1: 1$ mixture aerosol. The Raman spectra of the aerosols with mixing ratios of MBTCA $: \mathrm{NaCl}=1: 1,1: 2$, and $1: 3$ at the end of the dehydration process were unsuitable for the reactivity estimation mostly due to their heterogeneous structure in the presence of a $\mathrm{NaCl}$ core.

- Stages 4 and 5. The reaction proceeded after deliquescence, when the free $\mathrm{H}^{+}$and $\mathrm{Cl}^{-}$became available again for aerosols with mixing ratios of MBTCA $: \mathrm{NaCl}=1: 1,1: 2$, and $1: 3$, and a small increase in the degree of reaction $(\sim 5 \%)$ was observed at the end of humidification for these mixture droplets.

Most of the reactions occurred in the aqueous phase during the dehydration process with considerable amounts of aqueous $\mathrm{H}^{+}$from MBTCA and $\mathrm{Cl}^{-}$from $\mathrm{NaCl}$ available for $\mathrm{HCl}$ liberation. During the entire experiment, the reactivity followed the sequence of MBTCA: $\mathrm{NaCl}=2: 1>1: 3>1: 2>1: 1$, where the reactivity appeared to be enhanced when either of the reactants is enriched. On the other hand, the reaction was complete only when aqueous $\mathrm{H}^{+}$was sufficiently available; i.e., the reaction depended mostly on the triacid level. The real-time aerosol mixture components based on the reactivity estimation of each mixing ratio at specific RHs are shown on the hygroscopic curves in Figs. 4 and 5.

The morphology and elemental distribution of effloresced MBTCA-NaCl particles were examined by SEM-EDX. Figure $8 \mathrm{a}$ shows the secondary electron images (SEIs) of the exemplar particles of each mixing ratio. The elemental Xray maps for MBTCA: $\mathrm{NaCl}=1: 1$ and $1: 2$ particles suggest that the $\mathrm{NaCl}$ solid moiety (represented by $\mathrm{Na}$ and $\mathrm{Cl}$ $\mathrm{X}$-ray maps) crystallized homogeneously at small spots inside the organic moiety. For MBTCA: $\mathrm{NaCl}=1: 3$ particles with a significant amount of $\mathrm{NaCl}$, the $\mathrm{NaCl}$ solid existed as a core surrounded by the organic moiety. The organic mixture of MBTCA and $\mathrm{NaH}_{2} \mathrm{M}$ (represented by $\mathrm{C}$ and $\mathrm{Na}$ ) condensed onto the $\mathrm{NaCl}$ core almost simultaneously when efflorescence occurred while maintaining a relatively circular morphology, even after being inserted into the vacuum SEM chamber, which also indicates the low crystallization tendency of the organic moiety. The different shapes of organic-shell-inorganic-core structures depending on the organic mass fraction and $\mathrm{RH}$ are reported elsewhere (Karadima et al., 2019). The homogeneous structure of $\mathrm{C}$ and $\mathrm{Na}$ and the absence of $\mathrm{Cl}$ for particles with mixing ratios of MBTCA: $\mathrm{NaCl}=2: 1$, as shown in the corresponding SEIs and X-ray spectrum in Fig. 8a and b, confirmed that the reaction was complete at the end of the dehydration process. The reaction between MBTCA and $\mathrm{NaCl}$ and the changes in the microstructures after the reaction are expected to have some atmospheric implications since they may have enhanced ability to facilitate further heterogeneous reactions in the atmosphere because of their low-crystallization property. $\mathrm{Na}$ (from both $\mathrm{NaH}_{2} \mathrm{M}$ and $\mathrm{NaCl}$ ) and $\mathrm{Cl}$ (from $\mathrm{NaCl}$ ) levels were used to estimate the degrees of reaction for the MBTCA $: \mathrm{NaCl}=1: 1,1: 2,1: 3$, and $2: 1$ systems, which were estimated to be $\sim 25 \%, \sim 30 \%, \sim 37 \%$, and $100 \%$, respectively, matching well to those from the Raman analysis by $5 \%-8 \%$ differences.

\subsection{Hygroscopic behavior of pure MBTCA and MBTCA-NaCl mixture particles in the levitation system}

The data acquired from the levitation system for contactless experiments on particles of $\sim 80 \mu \mathrm{m}$ were used to compare with those obtained for aerosols on the Si wafer in the see-through impactor. The droplets were introduced into the levitator, dried rapidly at $\mathrm{RH}=\sim 10 \%$ within $15 \mathrm{~min}$ (first 

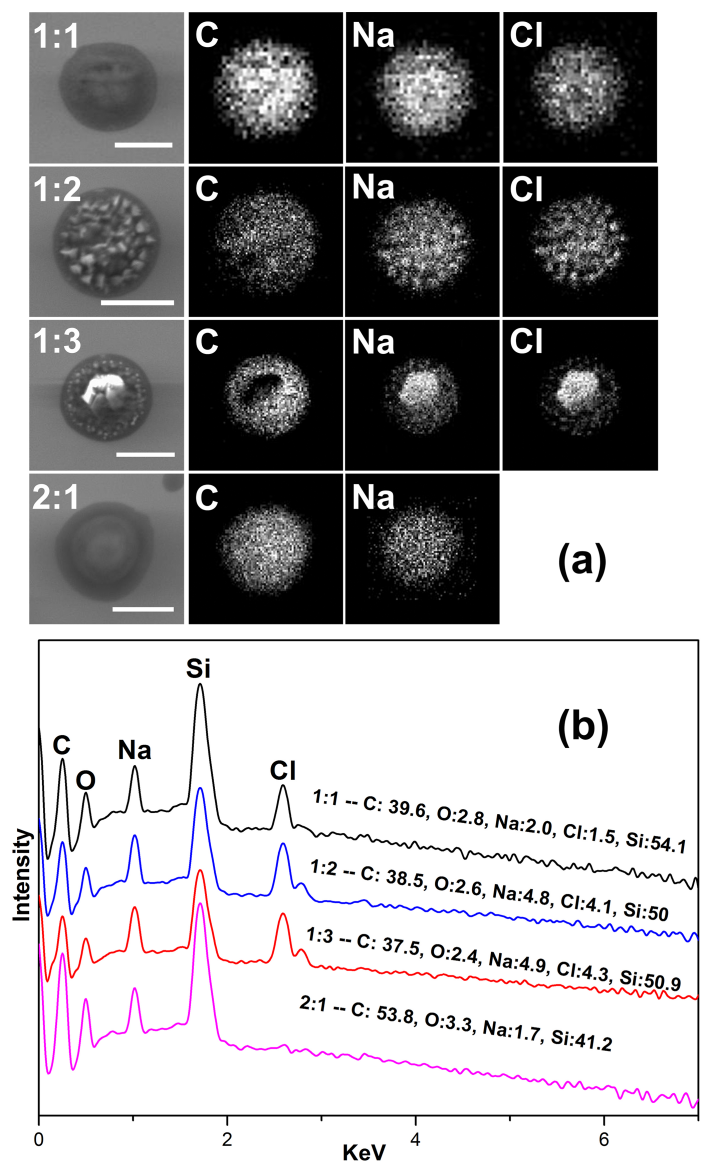

Figure 8. (a) Secondary electron images (SEIs) and elemental Xray maps for $\mathrm{C}$ (from $\mathrm{MBTCA}$ and $\mathrm{NaH}_{2} \mathrm{M}$ ), $\mathrm{Na}$ (from $\mathrm{NaH}_{2} \mathrm{M}$ and $\mathrm{NaCl}$ ), and $\mathrm{Cl}$ (from $\mathrm{NaCl}$ ). The scale bars are for $5 \mu \mathrm{m}$; (b) X-ray spectra and elemental concentrations of particles with four mixing ratios.

rapid dehydration, i.e., a quenching process), and humidified progressively to $\mathrm{RH}=80 \%$. Once $\mathrm{RH}=80 \%$, the particles were dehydrated gradually until $\mathrm{RH}=\sim 10 \%$ (second dehydration).

Two types of hygroscopic behavior of pure MBTCA particles were observed, corresponding closely to type 1 and 3 aerosol particles in the see-through impactor system, due to heterogeneous crystallization induced by impurity seed crystals and homogeneous crystallization, respectively, confirming that once the MBTCA particles overcome the kinetic barrier and effloresce into solids, they no longer capture water significantly. The ERH was $\sim 49 \%-54 \%$. The Raman spectra and optical images are not shown separately.

The Raman spectra and optical images of particles composed of MBTCA: $\mathrm{NaCl}=1: 1,1: 2$, and $1: 3$ mixing ratios are shown in Fig. 9. After the first rapid dehydration of the particles, the existence of peaks at 1655 and $1720 \mathrm{~cm}^{-1}$ was observed for all the mixtures, and the relative intensity of the peak at $\sim 1720 \mathrm{~cm}^{-1}$ increased with the increase in the $\mathrm{NaCl}$ content, suggesting the formation of the mixture of solid
MBTCA and amorphous moiety from either MBTCA or $\mathrm{NaH}_{2} \mathrm{M}$. During the humidification process, the Raman peak at $1720 \mathrm{~cm}^{-1}$ and the particle size grew continuously with increasing RH. Transitions were observed at $\mathrm{RH}=\sim 71 \%$, $\sim 74.5 \%$, and $\sim 75 \%$ for MBTCA: $\mathrm{NaCl}=1: 1,1: 2$, and $1: 3$ mixture particles, respectively, with the water peak at $\sim 3500 \mathrm{~cm}^{-1}$ becoming significant for the three compositions. The observed transition points were attributed to the deliquescence of $\mathrm{NaCl}$ within the particle with the MBTCA moiety partially remaining as a solid phase, and the elevated $\mathrm{NaCl}$ content strongly enhanced the ability of the particles to take up water. The peak related to the solid portion at $1655 \mathrm{~cm}^{-1}$ disappeared only for the MBTCA: $\mathrm{NaCl}=1: 3$ mixture particles at the end of humidification, suggesting that the particle had transformed completely into a droplet. During the second dehydration process, the particles showed the entire release of water, as illustrated by the disappearance of the peak at $3500 \mathrm{~cm}^{-1}$ at $\mathrm{RH}=\sim 50 \%$, i.e., the $\mathrm{ERH}$, for all the mixtures while maintaining the peak patterns and positions until the lowest RH. The Raman spectra recorded at the end of dehydration revealed both solid and amorphous phases for the MBTCA: $\mathrm{NaCl}=1: 1$ and $1: 2$ mixtures due to the existence of the peaks at 1655 and $1720 \mathrm{~cm}^{-1}$. In contrast, only the $1720 \mathrm{~cm}^{-1}$ associated with the amorphous composition was observed for the MBTCA: $\mathrm{NaCl}=1: 3$ mixture, suggesting that the reaction between MBTCA and $\mathrm{NaCl}$ was facilitated extensively by the increased $\mathrm{NaCl}$ concentration while absorbing sufficient moisture. The conspicuous DRHs and ERHs of all the mixtures in the levitation system demonstrated a smaller degree of reaction between MBTCA and $\mathrm{NaCl}$ compared to those obtained in the seethrough impactor, which might be caused by the relatively closed atmosphere in the levitator as the default settings of $\mathrm{N}_{2}$ flow inside the see-through impactor cell and the levitation cell were 4 and $0.2 \mathrm{~L} \mathrm{~min}^{-1}$, respectively, i.e., less release of $\mathrm{HCl}$. The larger size of the levitated particles could limit the release of $\mathrm{HCl}$ (Kerminen et al., 1997). In addition, the quenching process, i.e., the starting point of the hygroscopicity experiments, induced the solidification of MBTCA and, further, a slow reaction between MBTCA and $\mathrm{NaCl}$.

\section{Conclusions and atmospheric implication}

The hygroscopic behavior, physical states, and chemical reactivity of pure MBTCA particles, mono-/di-/trisodium MBTCA salt particles, and MBTCA-NaCl particles of different mixing ratios were examined by in situ RMS assembled with a see-through impactor as the starting point with dehydration. The DRHs and ERHs of the laboratorygenerated particles in the micrometer size range at room temperature were determined by monitoring the change in the particle area in the 2-D optical images and the corresponding Raman spectra at transition points with RH variation of $\sim 1 \%-95 \%$. Pure MBTCA showed three types 

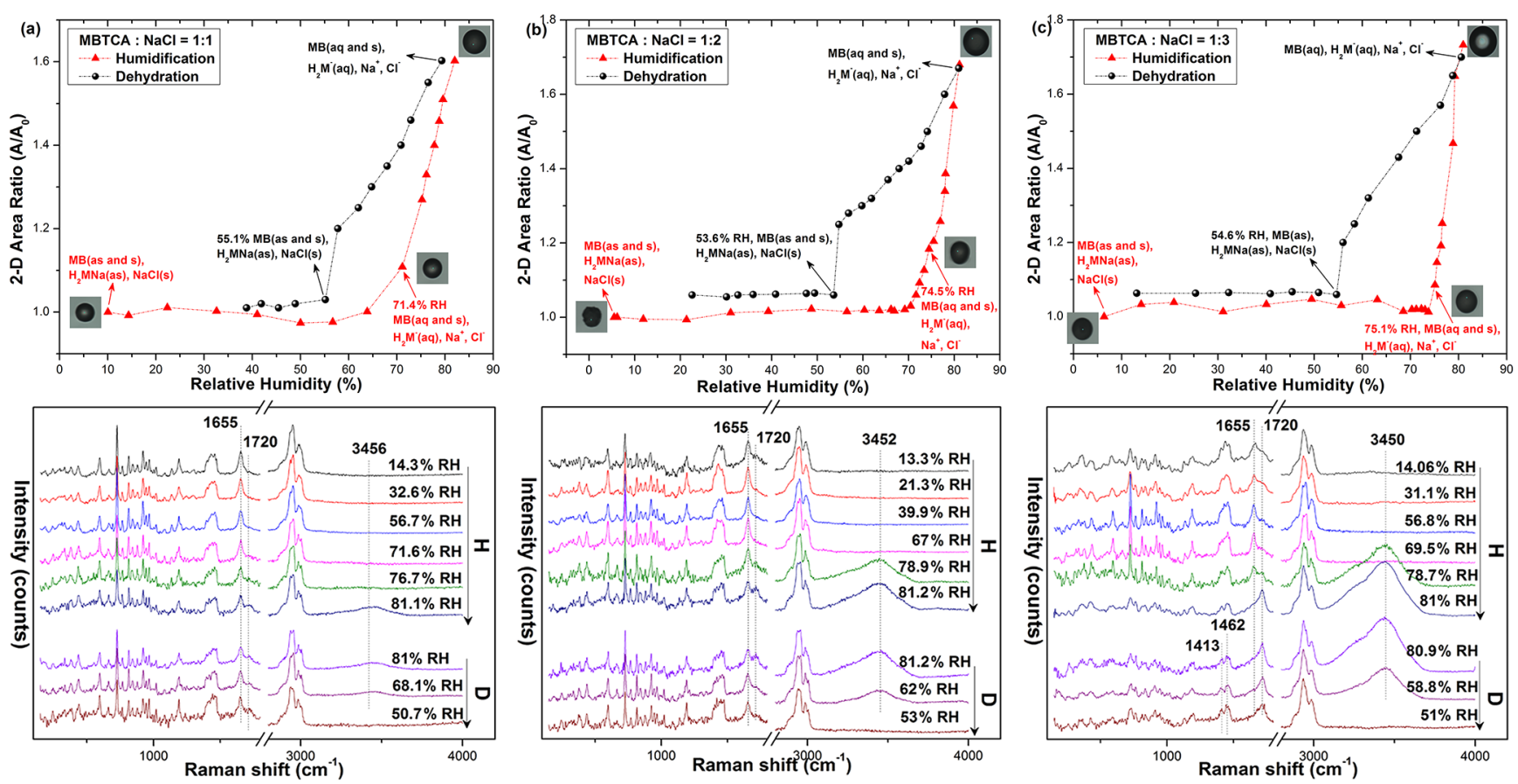

Figure 9. Hygroscopic curves, corresponding optical images, and Raman spectra at specific RHs of MBTCA: $\mathrm{NaCl}=($ a) $1: 1$, (b) $1: 2$, and (c) $1: 3$ mixture particles in the levitation system. The recorded transition RHs during the humidification (H) and dehydration (D) processes and the chemical compositions of the mixtures at certain RHs are marked with arrows in the hygroscopic curves. The phase notations shown in parentheses are s - solid, aq - aqueous, and as - amorphous solid.

of hygroscopic behaviors in that type 1 and 2 particles effloresced suddenly and gradually, respectively, at $\mathrm{ERH}=30 \%-58 \%$ during the dehydration process, whereas type 3 particles crystallized during the humidification process at $\mathrm{RH}=\sim 37 \%$, not during the dehydration process because of a kinetic barrier to nucleation with limited condensed water. Subsequently, all particles maintained their crystal structure until $\mathrm{RH}=95 \%$. The mono- and disodium MBTCA salt aerosols did not show a clear ERH and DRH during the dehydration and humidification processes, respectively. In contrast, the trisodium MBTCA showed $\mathrm{ERH}=\sim 44.4 \%-46.8 \%$ (during humidification) and DRH $=\sim 53.1 \%$. The MBTCA-NaCl droplets with molar mixing ratios of MBTCA $: \mathrm{NaCl}=1: 1$ and $2: 1$ showed no distinct DRH and ERH because of the partial and complete reactions with $\mathrm{NaCl}$, respectively, whereas those with ratios of MBTCA : $\mathrm{NaCl}=1: 2$ and $1: 3$ experienced singlestage efflorescence and deliquescence governed by the excess $\mathrm{NaCl}$. Only monosodium MBTCA $\left(\mathrm{NaH}_{2} \mathrm{M}\right)$ could be formed as a result of the reaction between $\mathrm{NaCl}$ and MBTCA regardless of the mixing ratios, mostly during the dehydration process within the timescale of 1 to $2 \mathrm{~h}$ according to Raman analysis, indicating that the MBTCA- $\mathrm{NaCl}$ mixture systems are in an MBTCA- $\mathrm{NaH}_{2} \mathrm{M}-\mathrm{NaCl}$ ternary system except when $\mathrm{NaCl}$ has reacted completely in the mixture aerosols with a ratio of MBTCA: $\mathrm{NaCl}=2: 1$. The MBTCA- $\mathrm{NaH}_{2} \mathrm{M}$ existed as amorphous solids, even when the excess crystalline $\mathrm{NaCl}$ acted as a heterogeneous nucleation core, which was also confirmed by X-ray mapping. The reaction occurred more rapidly with a more elevated concentration of either MBTCA or $\mathrm{NaCl}$, and the controlling factor for the reactivity of the mixtures depended mostly on the availability of $\mathrm{H}^{+}$dissociated from the MBTCA tricarboxylic acid. The hygroscopic experiments for pure MBTCA and MBTCA-NaCl mixture particles were also performed in a levitation system with the starting point from humidification after the quenching process and the $\mathrm{RH}$ variation of $\sim 10 \%$ to $80 \%$. The results acquired from the levitation system are consistent with those obtained from the see-through impactor, only with less reaction between MBTCA and $\mathrm{NaCl}$ resulting from the airtight atmosphere inside the levitator and the partial solidification of MBTCA after the quenching process. In addition, the elevated $\mathrm{NaCl}$ moiety can eventually transform the solidified MBTCA into droplets through reactions when absorbing adequate moisture.

These observations are expected to have important atmospheric implications in that they may help to better understand the complexity of real ambient SOA and inorganic-mixture particles. In this study, the hygroscopicity of MBTCA was altered significantly when mixed with $\mathrm{NaCl}$ due to the reaction so that they are more likely to contribute to further gas-particle interactions. The amorphous phase state may influence the uptake of gaseous photo-oxidants as well as the chemical transformation and aging of atmospheric 
aerosols (Mikhailov et al., 2009). The observed aqueous shell with the solid core upon the humidification of the mixture particles with mixing ratios of $\mathrm{MBTCA}: \mathrm{NaCl}=1: 2$ and $1: 3$ before the total dissolution of $\mathrm{NaCl}$ can scatter solar radiation more efficiently (Adachi et al., 2011; Sun et al., 2018). The aerosol liquid water can promote heterogeneous aqueous-phase chemical processes, resulting in the facile formation of secondary aerosols (Cheng et al., 2016; Li et al., 2019). Recently, heterogeneous reactions in aerosol water were reported to be a significant mechanism for haze formation in North China (Sun et al., 2018). Overall, the hygroscopic curve, Raman signatures, and X-ray maps of the effloresced particles provided clear features of the hygroscopic behavior and chemical reactivity of the $\mathrm{MBTCA}-\mathrm{NaCl}$ mixture system covered in this study. These results are expected to provide insights into the physicochemical characteristics and atmospheric chemistry of highly oxidized SOAs mixed with inorganic particles.

Data availability. The data used in this study are available upon request; please contact Chul-Un Ro (curo@inha.ac.kr).

Supplement. The supplement related to this article is available online at: https://doi.org/10.5194/acp-20-14103-2020-supplement.

Author contributions. LW, CB, SS, and CUR designed the experiment. LW, CB, and SS carried out the measurements and/or analyzed the data. LW, CB, SS, PMF, EP, EV, YCS, and CUR contributed discussion of the data. LW, SS, and CUR drafted the paper.

Competing interests. The authors declare that they have no conflict of interest.

Acknowledgements. This study was supported by Basic Science Research Programs through the National Research Foundation of Korea (NRF) funded by the Ministry of Education, Science, and Technology (grant no. NRF-2018R1A2A1A05023254) and by the Fine Particle National Strategic Project of the National Research Foundation of Korea (NRF) funded by the Ministry of Science and ICT (MSIT), the Ministry of Environment (ME), and the Ministry of Health and Welfare (MOHW; grant no. 2017M3D8A1090654). The authors thank the Region Nouvelle Aquitaine for the financial support of the SPECAERO project. This work was performed through international and collaborative programs supported by PHC STAR no. $38815 \mathrm{XE}$ and the visiting scholars program from IDEX of the University of Bordeaux.

Financial support. This research has been supported by the National Research Foundation of Korea (grant nos. NRF2018R1A2A1A05023254 and and 2017M3D8A1090654) and the University of Bordeaux (PHC STAR, grant no. 38815XE).
Review statement. This paper was edited by Alex Lee and reviewed by two anonymous referees.

\section{References}

Adachi, K., Freney, E. J., and Buseck, P. R.: Shapes of internally mixed hygroscopic aerosol particles after deliquescence, and their effect on light scattering, Geophys. Res. Lett., 38, L13804, https://doi.org/10.1029/2011g1047540, 2011.

Ahn, K.-H., Kim, S.-M., Jung, H.-J., Lee, M.-J., Eom, H.-J., Maskey, S., and Ro, C.-U.: Combined use of optical and electron microscopic techniques for the measurement of hygroscopic property, chemical composition, and morphology of individual aerosol particles, Anal. Chem., 82, 7999-8009, https://doi.org/10.1021/ac101432y, 2010

Aljawhary, D., Zhao, R., Lee, A. K., Wang, C., and Abbatt, J. P.: Kinetics, Mechanism, and Secondary Organic Aerosol Yield of Aqueous Phase Photo-oxidation of alphaPinene Oxidation Products, J. Phys. Chem. A, 120, 1395-1407, https://doi.org/10.1021/acs.jpca.5b06237, 2016.

An, P., Yuan, C.-Q., Liu, X.-H., Xiao, D.-B., and Luo, Z.-X.: Vibrational spectroscopic identification of isoprene, pinenes and their mixture, Chin. Chem. Lett., 27, 527-534, https://doi.org/10.1016/j.cclet.2016.01.036, 2016.

Bateman, A. P., Bertram, A. K., and Martin, S. T.: Hygroscopic influence on the semisolid-to-liquid transition of secondary organic materials, J. Phys. Chem. A, 119, 4386-4395, https://doi.org/10.1021/jp508521c, 2015a.

Bateman, A. P., Gong, Z., Liu, P., Sato, B., Cirino, G., Zhang, Y., Artaxo, P., Bertram, A. K., Manzi, A. O., Rizzo, L. V., Souza, R. A. F., Zaveri, R. A., and Martin, S. T.: Sub-micrometre particulate matter is primarily in liquid form over Amazon rainforest, Nat. Geosci., 9, 34-37, https://doi.org/10.1038/ngeo2599, 2015b.

Berkemeier, T., Shiraiwa, M., Pöschl, U., and Koop, T.: Competition between water uptake and ice nucleation by glassy organic aerosol particles, Atmos. Chem. Phys., 14, 12513-12531, https://doi.org/10.5194/acp-14-12513-2014, 2014.

Bernard, F., Ciuraru, R., Boreave, A., and George, C.: Photosensitized Formation of Secondary Organic Aerosols above the Air/Water Interface, Environ. Sci. Technol., 50, 8678-8686, https://doi.org/10.1021/acs.est.6b03520, 2016.

Bertran, O., Armelin, E., Estrany, F., Gomes, A., Torras, J., and Alemaìn, C.: Poly (2-thiophen-3-yl-malonic acid), a polythiophene with two carboxylic acids per repeating unit, J. Phys. Chem. B, 114, 6281-6290, https://doi.org/10.1021/jp1006796, 2010.

Cheng, Y., Zheng, G., Wei, C., Mu, Q., Zheng, B., Wang, Z., Gao, M., Zhang, Q., He, K., and Carmichael, G.: Reactive nitrogen chemistry in aerosol water as a source of sulfate during haze events in China, Sci. Adv., 2, e1601530, https://doi.org/10.1126/sciadv.1601530, 2016.

Chu, B., Wang, K., Takekawa, H., Li, J., Zhou, W., Jiang, J., Ma, Q., $\mathrm{He}, \mathrm{H}$., and Hao, J.: Hygroscopicity of particles generated from photooxidation of $\alpha$-pinene under different oxidation conditions in the presence of sulfate seed aerosols, J. Environ. Sci., 26, 129139, https://doi.org/10.1016/s1001-0742(13)60402-7, 2014.

Clegg, S. L., Seinfeld, J. H., and Edney, E. O.: Thermodynamic modelling of aqueous aerosols containing electrolytes and dissolved organic compounds. II. An extended Zdanovskii- 
Stokes-Robinson approach, J. Aerosol Sci., 34, 667-690, https://doi.org/10.1016/S0021-8502(03)00019-3, 2003.

Cui, T., Green, H. S., Selleck, P. W., Zhang, Z., O'Brien, R. E., Gold, A., Keywood, M., Kroll, J. H., and Surratt, J. D.: Chemical Characterization of Isoprene- and Monoterpene-Derived Secondary Organic Aerosol Tracers in Remote Marine Aerosols over a Quarter Century, ACS Earth Space Chem., 3, 935-946, https://doi.org/10.1021/acsearthspacechem.9b00061, 2019.

Dette, H. P., Qi, M., Schroder, D. C., Godt, A., and Koop, T.: Glass-forming properties of 3-methylbutane-1,2,3-tricarboxylic acid and its mixtures with water and pinonic acid, J. Phys. Chem. A, 118, 7024-7033, https://doi.org/10.1021/jp505910w, 2014.

Ding, X., Wang, X.-M., Gao, B., Fu, X.-X., He, Q.-F., Zhao, X.-Y., Yu, J.-Z., and Zheng, M.: Tracer-based estimation of secondary organic carbon in the Pearl River Delta, south China, J. Geophys. Res.-Atmos., 117, D05313, https://doi.org/10.1029/2011jd016596, 2012.

Donahue, N. M., Henry, K. M., Mentel, T. F., Kiendler-Scharr, A., Spindler, C., Bohn, B., Brauers, T., Dorn, H. P., Fuchs, H., Tillmann, R., Wahner, A., Saathoff, H., Naumann, K. H., Mohler, O., Leisner, T., Muller, L., Reinnig, M. C., Hoffmann, T., Salo, K., Hallquist, M., Frosch, M., Bilde, M., Tritscher, T., Barmet, P., Praplan, A. P., DeCarlo, P. F., Dommen, J., Prevot, A. S., and Baltensperger, U.: Aging of biogenic secondary organic aerosol via gas-phase $\mathrm{OH}$ radical reactions, P. Natl. Acad. Sci. USA, 109, 13503-13508, https://doi.org/10.1073/pnas.1115186109, 2012.

Dunne, E. M., Gordon, H., Kurten, A., Almeida, J., Duplissy, J., Williamson, C., Ortega, I. K., Pringle, K. J., Adamov, A., Baltensperger, U., Barmet, P., Benduhn, F., Bianchi, F., Breitenlechner, M., Clarke, A., Curtius, J., Dommen, J., Donahue, N. M., Ehrhart, S., Flagan, R. C., Franchin, A., Guida, R., Hakala, J., Hansel, A., Heinritzi, M., Jokinen, T., Kangasluoma, J., Kirkby, J., Kulmala, M., Kupc, A., Lawler, M. J., Lehtipalo, K., Makhmutov, V., Mann, G., Mathot, S., Merikanto, J., Miettinen, P., Nenes, A., Onnela, A., Rap, A., Reddington, C. L., Riccobono, F., Richards, N. A., Rissanen, M. P., Rondo, L., Sarnela, N., Schobesberger, S., Sengupta, K., Simon, M., Sipila, M., Smith, J. N., Stozkhov, Y., Tome, A., Trostl, J., Wagner, P. E., Wimmer, D., Winkler, P. M., Worsnop, D. R., and Carslaw, K. S.: Global atmospheric particle formation from CERN CLOUD measurements, Science, 354, 1119-1124, https://doi.org/10.1126/science.aaf2649, 2016.

Edsall, J. T.: Raman Spectra of Amino Acids and Related Compounds IV. Ionization of Di- and Tricarboxylic Acids, J. Chem. Phys., 5, 508-517, https://doi.org/10.1063/1.1750067, 1937.

Enami, S. and Sakamoto, Y.: OH-Radical Oxidation of Surface-Active cis-Pinonic Acid at the AirWater Interface, J. Phys. Chem. A, 120, 3578-3587, https://doi.org/10.1021/acs.jpca.6b01261, 2016.

Eom, H. J., Gupta, D., Li, X., Jung, H. J., Kim, H., and Ro, C. U.: Influence of collecting substrates on the characterization of hygroscopic properties of inorganic aerosol particles, Anal. Chem., 86, 2648-2656, https://doi.org/10.1021/ac4042075, 2014.

Freedman, M. A.: Phase separation in organic aerosol, Chem. Soc. Rev., 46, 7694-7705, https://doi.org/10.1039/C6CS00783J, 2017.

Fu, P., Kawamura, K., Chen, J., and Barrie, L. A.: Isoprene, monoterpene, and sesquiterpene oxidation products in the high Arctic aerosols during late winter to early summer, Environ. Sci.
Technol., 43, 4022-4028, https://doi.org/10.1021/es803669a, 2009.

Fu, P. Q., Kawamura, K., Cheng, Y. F., Hatakeyama, S., Takami, A., Li, H., and Wang, W.: Aircraft measurements of polar organic tracer compounds in tropospheric particles $\left(\mathrm{PM}_{10}\right)$ over central China, Atmos. Chem. Phys., 14, 4185-4199, https://doi.org/10.5194/acp-14-4185-2014, 2014.

Ge, Z., Wexler, A. S., and Johnston, M. V.: Multicomponent aerosol crystallization, J. Colloid Interf. Sci., 183, 68-77, https://doi.org/10.1006/jcis.1996.0519, 1996.

Gibson, E. R., Hudson, P. K., and Grassian, V. H.: Physicochemical properties of nitrate aerosols: Implications for the atmosphere, J. Phys. Chem. A, 110, 11785-11799, https://doi.org/10.1021/jp063821k, 2006.

Gómez-González, Y., Wang, W., Vermeylen, R., Chi, X., Neirynck, J., Janssens, I. A., Maenhaut, W., and Claeys, M.: Chemical characterisation of atmospheric aerosols during a 2007 summer field campaign at Brasschaat, Belgium: sources and source processes of biogenic secondary organic aerosol, Atmos. Chem. Phys., 12, 125-138, https://doi.org/10.5194/acp-12-125-2012, 2012.

Guenther, A., Hewitt, C. N., Erickson, D., Fall, R., Geron, C., Graedel, T., Harley, P., Klinger, L., Lerdau, M., and McKay, W.: A global model of natural volatile organic compound emissions, J. Geophys. Res.-Atmos., 100, 8873-8892, https://doi.org/10.1029/94JD02950, 1995.

Gupta, D., Eom, H.-J., Cho, H.-R., and Ro, C.-U.: Hygroscopic behavior of $\mathrm{NaCl}-\mathrm{MgCl}_{2}$ mixture particles as nascent seaspray aerosol surrogates and observation of efflorescence during humidification, Atmos. Chem. Phys., 15, 11273-11290, https://doi.org/10.5194/acp-15-11273-2015, 2015.

Gysel, M., Weingartner, E., and Baltensperger, U.: Hygroscopicity of aerosol particles at low temperatures. 2. Theoretical and experimental hygroscopic properties of laboratory generated aerosols, Environ. Sci. Technol., 36, 63-68, https://doi.org/10.1021/es010055g, 2002.

Hallquist, M., Wenger, J. C., Baltensperger, U., Rudich, Y., Simpson, D., Claeys, M., Dommen, J., Donahue, N. M., George, C., Goldstein, A. H., Hamilton, J. F., Herrmann, H., Hoffmann, T., Iinuma, Y., Jang, M., Jenkin, M. E., Jimenez, J. L., Kiendler-Scharr, A., Maenhaut, W., McFiggans, G., Mentel, Th. F., Monod, A., Prévôt, A. S. H., Seinfeld, J. H., Surratt, J. D., Szmigielski, R., and Wildt, J.: The formation, properties and impact of secondary organic aerosol: current and emerging issues, Atmos. Chem. Phys., 9, 5155-5236, https://doi.org/10.5194/acp9-5155-2009, 2009.

Harris, D. C.: Exploring chemical analysis, 5th edition, Macmillan Learning, New York, USA, 2012.

Haywood, J. and Boucher, O.: Estimates of the direct and indirect radiative forcing due to tropospheric aerosols: A review, Rev. Geophys., 38, 513-543, https://doi.org/10.1029/1999RG000078, 2000.

Hoffman, R. C., Laskin, A., and Finlayson-Pitts, B. J.: Sodium nitrate particles: physical and chemical properties during hydration and dehydration, and implications for aged sea salt aerosols, J. Aerosol Sci., 35, 869-887, https://doi.org/10.1016/j.jaerosci.2004.02.003, 2004.

Holopainen, J. K., Kivimaenpaa, M., and Nizkorodov, S. A.: Plant-derived Secondary Organic Material in the 
Air and Ecosystems, Trends Plant Sci., 22, 744-753, https://doi.org/10.1016/j.tplants.2017.07.004, 2017.

Hong, Z., Zhang, H., Zhang, Y., Xu, L., Liu, T., Xiao, H., Hong, Y., Chen, J., Li, M., Deng, J., Wu, X., Hu, B., and Chen, X.: Secondary organic aerosol of PM2.5 in a mountainous forest area in southeastern China: Molecular compositions and tracers implication, Sci. Total. Environ., 653, 496-503, https://doi.org/10.1016/j.scitotenv.2018.10.370, 2019.

Hu, D., Bian, Q., Li, T. W. Y., Lau, A. K. H., and Yu, J. Z.: Contributions of isoprene, monoterpenes, $\beta$-caryophyllene, and toluene to secondary organic aerosols in Hong Kong during the summer of 2006, J. Geophys. Res., 113, D22206, https://doi.org/10.1029/2008jd010437, 2008.

Hu, Q. H., Xie, Z. Q., Wang, X. M., Kang, H., He, Q. F., and Zhang, P.: Secondary organic aerosols over oceans via oxidation of isoprene and monoterpenes from Arctic to Antarctic, Sci. Rep., 3, 2280, https://doi.org/10.1038/srep02280, 2013.

Jang, M., Czoschke, N. M., Lee, S., and Kamens, R. M.: Heterogeneous atmospheric aerosol production by acidcatalyzed particle-phase reactions, Science, 298, 814-817, https://doi.org/10.1126/science.1075798, 2002.

Jaoui, M., Kleindienst, T., Lewandowski, M., Offenberg, J., and Edney, E.: Identification and quantification of aerosol polar oxygenated compounds bearing carboxylic or hydroxyl groups. 2 . Organic tracer compounds from monoterpenes, Environ. Sci. Technol., 39, 5661-5673, https://doi.org/10.1021/es048111b, 2005.

Jimenez, J. L., Canagaratna, M., Donahue, N., Prevot, A., Zhang, Q., Kroll, J. H., DeCarlo, P. F., Allan, J. D., Coe, H., and Ng, N.: Evolution of organic aerosols in the atmosphere, science, 326, 1525-1529, https://doi.org/10.1126/science.1180353, 2009.

Jing, B., Tong, S., Liu, Q., Li, K., Wang, W., Zhang, Y., and Ge, M.: Hygroscopic behavior of multicomponent organic aerosols and their internal mixtures with ammonium sulfate, Atmos. Chem. Phys., 16, 4101-4118, https://doi.org/10.5194/acp-164101-2016, 2016.

Jing, B., Wang, Z., Tan, F., Guo, Y., Tong, S., Wang, W., Zhang, Y., and Ge, M.: Hygroscopic behavior of atmospheric aerosols containing nitrate salts and water-soluble organic acids, Atmos. Chem. Phys., 18, 5115-5127, https://doi.org/10.5194/acp18-5115-2018, 2018.

Kammer, J., Perraudin, E., Flaud, P. M., Lamaud, E., Bonnefond, J. M., and Villenave, E.: Observation of nighttime new particle formation over the French Landes forest, Sci. Total. Environ., 621, 1084-1092, https://doi.org/10.1016/j.scitotenv.2017.10.118, 2018.

Kang, M., Fu, P., Kawamura, K., Yang, F., Zhang, H., Zang, Z., Ren, H., Ren, L., Zhao, Y., Sun, Y., and Wang, Z.: Characterization of biogenic primary and secondary organic aerosols in the marine atmosphere over the East China Sea, Atmos. Chem. Phys., 18, 13947-13967, https://doi.org/10.5194/acp-18-139472018, 2018.

Karadima, K. S., Mavrantzas, V. G., and Pandis, S. N.: Insights into the morphology of multicomponent organic and inorganic aerosols from molecular dynamics simulations, Atmos. Chem. Phys., 19, 5571-5587, https://doi.org/10.5194/acp-195571-2019, 2019.

Kerminen, V.-M., Pakkanen, T. A., and Hillamo, R. E.: Interactions between inorganic trace gases and supermicrometer particles at a coastal site, Atmos. Environ., 31, 2753-2765, https://doi.org/10.1016/S1352-2310(97)00092-7, 1997.

Kidd, C., Perraud, V., Wingen, L. M., and Finlayson-Pitts, B. J.: Integrating phase and composition of secondary organic aerosol from the ozonolysis of $\alpha$-pinene, P. Natl. Acad. Sci. USA, 111, 7552-7557, https://doi.org/10.1073/pnas.1322558111, 2014.

Kildgaard, J. V., Mikkelsen, K. V., Bilde, M., and Elm, J.: Hydration of Atmospheric Molecular Clusters II: Organic Acid-Water Clusters, J. Phys. Chem. A, 122, 8549-8556, https://doi.org/10.1021/acs.jpca.8b07713, 2018.

Kim, H., Lee, M.-J., Jung, H.-J., Eom, H.-J., Maskey, S., Ahn, K.-H., and Ro, C.-U.: Hygroscopic behavior of wet dispersed and dry deposited $\mathrm{NaNO}_{3}$ particles, Atmos. Environ., 60, 68-75, https://doi.org/10.1016/j.atmosenv.2012.06.011, 2012.

Kim, H., Zhang, Q., and Heo, J.: Influence of intense secondary aerosol formation and long-range transport on aerosol chemistry and properties in the Seoul Metropolitan Area during spring time: results from KORUS-AQ, Atmos. Chem. Phys., 18, 71497168, https://doi.org/10.5194/acp-18-7149-2018, 2018.

Koop, T., Bookhold, J., Shiraiwa, M., and Pöschl, U.: Glass transition and phase state of organic compounds: dependency on molecular properties and implications for secondary organic aerosols in the atmosphere, Phys. Chem. Chem. Phys., 13, 19238-19255, https://doi.org/10.1039/C1CP22617G, 2011.

Kostenidou, E., Karnezi, E., Kolodziejczyk, A., Szmigielski, R., and Pandis, S. N.: Physical and Chemical Properties of 3-Methyl-1,2,3-butanetricarboxylic Acid (MBTCA) Aerosol, Environ. Sci. Technol., 52, 1150-1155, https://doi.org/10.1021/acs.est.7b04348, 2018.

Kourtchev, I., Copolovici, L., Claeys, M., and Maenhaut, W.: Characterization of atmospheric aerosols at a forested site in Central Europe, Environ. Sci. Technol., 43, 4665-4671, https://doi.org/10.1021/es803055w, 2009.

Kroll, J. H. and Seinfeld, J. H.: Chemistry of secondary organic aerosol: Formation and evolution of low-volatility organics in the atmosphere, Atmos. Environ., 42, 3593-3624, https://doi.org/10.1016/j.atmosenv.2008.01.003, 2008.

Kubátová, A., Vermeylen, R., Claeys, M., Cafmeyer, J., Maenhaut, W., Roberts, G., and Artaxo, P.: Carbonaceous aerosol characterization in the Amazon basin, Brazil: novel dicarboxylic acids and related compounds, Atmos. Environ., 34, 5037-5051, https://doi.org/10.1016/S1352-2310(00)00320-4, 2000.

Kubátová, A., Vermeylen, R., Claeys, M., Cafmeyer, J., and Maenhaut, W.: Organic compounds in urban aerosols from Gent, Belgium: Characterization, sources, and seasonal differences, J. Geophys. Res.-Atmos., 107, 8343, https://doi.org/10.1029/2001jd000556, 2002.

Lai, C., Liu, Y., Ma, J., Ma, Q., Chu, B., and He, H.: Heterogeneous Kinetics of cis-Pinonic Acid with Hydroxyl Radical under Different Environmental Conditions, J. Phys. Chem. A, 119, 65836593, https://doi.org/10.1021/acs.jpca.5b01321, 2015.

Laskin, A., Moffet, R. C., Gilles, M. K., Fast, J. D., Zaveri, R. A., Wang, B., Nigge, P., and Shutthanandan, J.: Tropospheric chemistry of internally mixed sea salt and organic particles: Surprising reactivity of $\mathrm{NaCl}$ with weak organic acids, J. Geophys. Res.Atmos., 117, D15302, https://doi.org/10.1029/2012jd017743, 2012.

Lee, A. K. Y., Ling, T. Y., and Chan, C. K.: Understanding hygroscopic growth and phase transformation of aerosols using single 
particle Raman spectroscopy in an electrodynamic balance, Faraday Discuss., 137, 245-263, https://doi.org/10.1039/b704580h, 2008.

Lessmeier, J., Dette, H. P., Godt, A., and Koop, T.: Physical state of 2-methylbutane-1,2,3,4-tetraol in pure and internally mixed aerosols, Atmos. Chem. Phys., 18, 15841-15857, https://doi.org/10.5194/acp-18-15841-2018, 2018.

Li, J. J., Wang, G. H., Cao, J. J., Wang, X. M., and Zhang, R. J.: Observation of biogenic secondary organic aerosols in the atmosphere of a mountain site in central China: temperature and relative humidity effects, Atmos. Chem. Phys., 13, 11535-11549, https://doi.org/10.5194/acp-13-11535-2013, 2013.

Li, X., Gupta, D., Eom, H.-J., Kim, H., and Ro, C.-U.: Deliquescence and efflorescence behavior of individual $\mathrm{NaCl}$ and $\mathrm{KCl}$ mixture aerosol particles, Atmos. Environ., 82, 36-43, https://doi.org/10.1016/j.atmosenv.2013.10.011, 2014.

Li, X., Gupta, D., Lee, J., Park, G., and Ro, C. U.: Real-Time Investigation of Chemical Compositions and Hygroscopic Properties of Aerosols Generated from $\mathrm{NaCl}$ and Malonic Acid Mixture Solutions Using in Situ Raman Microspectrometry, Environ. Sci. Technol., 51, 263-270, https://doi.org/10.1021/acs.est.6b04356, 2017.

Li, X., Song, S., Zhou, W., Hao, J., Worsnop, D. R., and Jiang, J.: Interactions between aerosol organic components and liquid water content during haze episodes in Beijing, Atmos. Chem. Phys., 19, 12163-12174, https://doi.org/10.5194/acp-19-121632019, 2019.

Lightstone, J. M., Onasch, T. B., Imre, D., and Oatis, S.: Deliquescence, efflorescence, and water activity in ammonium nitrate and mixed ammonium nitrate/succinic acid microparticles, J. Phys. Chem. A, 104, 9337-9346, https://doi.org/10.1021/jp002137h, 2000.

Lignell, H., Epstein, S. A., Marvin, M. R., Shemesh, D., Gerber, B., and Nizkorodov, S.: Experimental and theoretical study of aqueous cis-pinonic acid photolysis, J. Phys. Chem. A, 117, 1293012945, https://doi.org/10.1021/jp4093018, 2013.

Liu, T., Zhou, L., Liu, Q., Lee, B. P., Yao, D., Lu, H., Lyu, X., Guo, H., and Chan, C. K.: Secondary Organic Aerosol Formation from Urban Roadside Air in Hong Kong, Environ. Sci. Technol., 53, 3001-3009, https://doi.org/10.1021/acs.est.8b06587, 2019.

Ma, Q., Ma, J., Liu, C., Lai, C., and He, H.: Laboratory study on the hygroscopic behavior of external and internal C2-C4 dicarboxylic acid-NaCl mixtures, Environ. Sci. Technol., 47, 1038110388, https://doi.org/10.1021/es4023267, 2013.

Marsh, A., Rovelli, G., Miles, R. E. H., and Reid, J. P.: Complexity of Measuring and Representing the Hygroscopicity of Mixed Component Aerosol, J. Phys. Chem. A, 123, 1648-1660, https://doi.org/10.1021/acs.jpca.8b11623, 2019.

Martin, S. T.: Phase transitions of aqueous atmospheric particles, Chem. Rev., 100, 3403-3454, https://doi.org/10.1021/cr990034t, 2000.

Mikhailov, E., Vlasenko, S., Martin, S. T., Koop, T., and Pöschl, U.: Amorphous and crystalline aerosol particles interacting with water vapor: conceptual framework and experimental evidence for restructuring, phase transitions and kinetic limitations, Atmos. Chem. Phys., 9, 9491-9522, https://doi.org/10.5194/acp-9-94912009, 2009.

Miyazaki, Y., Jung, J., Fu, P., Mizoguchi, Y., Yamanoi, K., and Kawamura, K.: Evidence of formation of submicrometer water- soluble organic aerosols at a deciduous forest site in northern Japan in summer, J. Geophys. Res.-Atmos., 117, D19213, https://doi.org/10.1029/2012jd018250, 2012.

Müller, L., Reinnig, M.-C., Naumann, K. H., Saathoff, H., Mentel, T. F., Donahue, N. M., and Hoffmann, T.: Formation of 3methyl-1,2,3-butanetricarboxylic acid via gas phase oxidation of pinonic acid - a mass spectrometric study of SOA aging, Atmos. Chem. Phys., 12, 1483-1496, https://doi.org/10.5194/acp12-1483-2012, 2012.

Mutzel, A., Rodigast, M., Iinuma, Y., Böge, O., and Herrmann, H.: Monoterpene SOA-contribution of firstgeneration oxidation products to formation and chemical composition, Atmos. Environ., 130, 136-144, https://doi.org/10.1016/j.atmosenv.2015.10.080, 2016.

Pajunoja, A., Hu, W., Leong, Y. J., Taylor, N. F., Miettinen, P., Palm, B. B., Mikkonen, S., Collins, D. R., Jimenez, J. L., and Virtanen, A.: Phase state of ambient aerosol linked with water uptake and chemical aging in the southeastern US, Atmos. Chem. Phys., 16, 11163-11176, https://doi.org/10.5194/acp-16-111632016, 2016.

Parsons, M. T., Knopf, D. A., and Bertram, A. K.: Deliquescence and Crystallization of Ammonium Sulfate Particles Internally Mixed with Water-Soluble Organic Compounds, J. Phys. Chem. A, 108, 11600-11608, https://doi.org/10.1021/jp0462862, 2004.

Pöhlker, C., Saturno, J., Krüger, M. L., Förster, J.-D., Weigand, M., Wiedemann, K. T., Bechtel, M., Artaxo, P., and Andreae, M. O.: Efflorescence upon humidification? X-ray microspectroscopic in situ observation of changes in aerosol microstructure and phase state upon hydration, Geophys. Res. Lett., 41, 368-13689, https://doi.org/10.1002/2014g1059409, 2014.

Pöschl, U. and Shiraiwa, M.: Multiphase chemistry at the atmosphere-biosphere interface influencing climate and public health in the anthropocene, Chem. Rev., 115, 4440-4475, https://doi.org/10.1021/cr500487s, 2015.

Praplan, A. P., Barmet, P., Dommen, J., and Baltensperger, U.: Cyclobutyl methyl ketone as a model compound for pinonic acid to elucidate oxidation mechanisms, Atmos. Chem. Phys., 12, 10749-10758, https://doi.org/10.5194/acp-12-10749-2012, 2012.

Reid, J. P., Bertram, A. K., Topping, D. O., Laskin, A., Martin, S. T., Petters, M. D., Pope, F. D., and Rovelli, G.: The viscosity of atmospherically relevant organic particles, Nat. Commun., 9, 956, https://doi.org/10.1038/s41467-018-03027-z, 2018.

Renbaum-Wolff, L., Grayson, J. W., Bateman, A. P., Kuwata, M., Sellier, M., Murray, B. J., Shilling, J. E., Martin, S. T., and Bertram, A. K.: Viscosity of alpha-pinene secondary organic material and implications for particle growth and reactivity, P. Natl. Acad. Sci. USA, 110, 8014-8019, https://doi.org/10.1073/pnas.1219548110, 2013.

Rudich, Y., Donahue, N. M., and Mentel, T. F.: Aging of organic aerosol: Bridging the gap between laboratory and field studies, Annu. Rev. Phys. Chem., 58, 321-352, https://doi.org/10.1146/annurev.physchem.58.032806.104432, 2007.

Sato, K., Jia, T., Tanabe, K., Morino, Y., Kajii, Y., and Imamura, T.: Terpenylic acid and nine-carbon multifunctional compounds formed during the aging of $\beta$-pinene ozonolysis secondary organic aerosol, Atmos. Environ., 130, 127-135, https://doi.org/10.1016/j.atmosenv.2015.08.047, 2016. 
Saukko, E., Lambe, A. T., Massoli, P., Koop, T., Wright, J. P., Croasdale, D. R., Pedernera, D. A., Onasch, T. B., Laaksonen, A., Davidovits, P., Worsnop, D. R., and Virtanen, A.: Humiditydependent phase state of SOA particles from biogenic and anthropogenic precursors, Atmos. Chem. Phys., 12, 7517-7529, https://doi.org/10.5194/acp-12-7517-2012, 2012.

Schlenker, J. C. and Martin, S. T.: Crystallization pathways of sulfate-nitrate-ammonium aerosol particles, J. Phys. Chem. A, 109, 9980-9985, https://doi.org/10.1021/jp052973x, 2005.

Seaver, M., Galloway, A., and Manuccia, T. J.: Acoustic levitation in a free-jet wind tunnel, Rev. Sci. Instrum., 60, 3452-3459, https://doi.org/10.1063/1.1140492, 1989.

Seng, S., Guo, F., Tobon, Y. A., Ishikawa, T., Moreau, M., Ishizaka, S., and Sobanska, S.: Deliquescence behavior of photoirradiated single $\mathrm{NaNO}_{3}$ droplets, Atmos. Environ., 183, 33-39, https://doi.org/10.1016/j.atmosenv.2018.04.007, 2018.

Shiraiwa, M., Li, Y., Tsimpidi, A. P., Karydis, V. A., Berkemeier, T., Pandis, S. N., Lelieveld, J., Koop, T., and Pöschl, U.: Global distribution of particle phase state in atmospheric secondary organic aerosols, Nat. Commun., 8, 15002, https://doi.org/10.1038/ncomms15002, 2017.

Shrivastava, M., Easter, R. C., Liu, X., Zelenyuk, A., Singh, B., Zhang, K., Ma, P.-L., Chand, D., Ghan, S., Jimenez, J. L., Zhang, Q., Fast, J., Rasch, P. J., and Tiitta, P.: Global transformation and fate of SOA: Implications of low-volatility SOA and gas-phase fragmentation reactions, J. Geophys. Res.-Atmos., 120, 41694195, https://doi.org/10.1002/2014jd022563, 2015.

Shrivastava, M., Cappa, C. D., Fan, J., Goldstein, A. H., Guenther, A. B., Jimenez, J. L., Kuang, C., Laskin, A., Martin, S. T., Ng, N. L., Petaja, T., Pierce, J. R., Rasch, P. J., Roldin, P., Seinfeld, J. H., Shilling, J., Smith, J. N., Thornton, J. A., Volkamer, R., Wang, J., Worsnop, D. R., Zaveri, R. A., Zelenyuk, A., and Zhang, Q.: Recent advances in understanding secondary organic aerosol: Implications for global climate forcing, Rev. Geophys., 55, 509559, https://doi.org/10.1002/2016rg000540, 2017.

Slade, J. H., Ault, A. P., Bui, A. T., Ditto, J. C., Lei, Z., Bondy, A. L., Olson, N. E., Cook, R. D., Desrochers, S. J., Harvey, R. M., Erickson, M. H., Wallace, H. W., Alvarez, S. L., Flynn, J. H., Boor, B. E., Petrucci, G. A., Gentner, D. R., Griffin, R. J., and Shepson, P. B.: Bouncier Particles at Night: Biogenic Secondary Organic Aerosol Chemistry and Sulfate Drive Diel Variations in the Aerosol Phase in a Mixed Forest, Environ. Sci. Technol., 53, 4977-4987, https://doi.org/10.1021/acs.est.8b07319, 2019.

Song, M., Maclean, A. M., Huang, Y., Smith, N. R., Blair, S. L., Laskin, J., Laskin, A., DeRieux, W.-S. W., Li, Y., Shiraiwa, M., Nizkorodov, S. A., and Bertram, A. K.: Liquid-liquid phase separation and viscosity within secondary organic aerosol generated from diesel fuel vapors, Atmos. Chem. Phys., 19, 12515-12529, https://doi.org/10.5194/acp-19-12515-2019, 2019.

Song, Y. C., Haddrell, A. E., Bzdek, B. R., Reid, J. P., Bannan, T., Topping, D. O., Percival, C., and Cai, C.: Measurements and predictions of binary component aerosol particle viscosity, J. Phys. Chem. A, 120, 8123-8137, https://doi.org/10.1021/acs.jpca.6b07835, 2016.

Srivastava, D., Favez, O., Perraudin, E., Villenave, E., and Albinet, A.: Comparison of Measurement-Based Methodologies to Apportion Secondary Organic Carbon (SOC) in $\mathrm{PM}_{2.5}$ : A Review of Recent Studies, Atmosphere, 9, 452, https://doi.org/10.3390/atmos9110452, 2018.
Sun, J., Liu, L., Xu, L., Wang, Y., Wu, Z., Hu, M., Shi, Z., Li, Y., Zhang, X., Chen, J., and Li, W.: Key Role of Nitrate in Phase Transitions of Urban Particles: Implications of Important Reactive Surfaces for Secondary Aerosol Formation, J. Geophys. Res.-Atmos., 123, 1234-1243, https://doi.org/10.1002/2017jd027264, 2018.

Szmigielski, R., Surratt, J. D., Gómez-González, Y., Van der Veken, P., Kourtchev, I., Vermeylen, R., Blockhuys, F., Jaoui, M., Kleindienst, T. E., Lewandowski, M., Offenberg, J. H., Edney, E. O., Seinfeld, J. H., Maenhaut, W., and Claeys, M.: 3-methyl1,2,3-butanetricarboxylic acid: An atmospheric tracer for terpene secondary organic aerosol, Geophys. Res. Lett., 34, L24811, https://doi.org/10.1029/2007gl031338, 2007.

Tang, M., Chan, C. K., Li, Y. J., Su, H., Ma, Q., Wu, Z., Zhang, G., Wang, Z., Ge, M., Hu, M., He, H., and Wang, X.: A review of experimental techniques for aerosol hygroscopicity studies, Atmos. Chem. Phys., 19, 12631-12686, https://doi.org/10.5194/acp-1912631-2019, 2019.

Topping, D., Connolly, P., and McFiggans, G.: Cloud droplet number enhanced by co-condensation of organic vapours, Nat Geosci., 6, 443-446, https://doi.org/10.1038/ngeo1809, 2013.

Virtanen, A., Joutsensaari, J., Koop, T., Kannosto, J., Yli-Pirilä, P., Leskinen, J., Mäkelä, J. M., Holopainen, J. K., Pöschl, U., and Kulmala, M.: An amorphous solid state of biogenic secondary organic aerosol particles, Nature, 467, 824-827, https://doi.org/10.1038/nature09455, 2010.

Vlachou, A., Tobler, A., Lamkaddam, H., Canonaco, F., Daellenbach, K. R., Jaffrezo, J.-L., Minguillón, M. C., Maasikmets, M., Teinemaa, E., Baltensperger, U., El Haddad, I., and Prévôt, A. S. H.: Development of a versatile source apportionment analysis based on positive matrix factorization: a case study of the seasonal variation of organic aerosol sources in Estonia, Atmos. Chem. Phys., 19, 7279-7295, https://doi.org/10.5194/acp19-7279-2019, 2019.

Vogel, A. L., Äijälä, M., Corrigan, A. L., Junninen, H., Ehn, M., Petäjä, T., Worsnop, D. R., Kulmala, M., Russell, L. M., Williams, J., and Hoffmann, T.: In situ submicron organic aerosol characterization at a boreal forest research station during HUMPPA-COPEC 2010 using soft and hard ionization mass spectrometry, Atmos. Chem. Phys., 13, 10933-10950, https://doi.org/10.5194/acp-13-10933-2013, 2013.

Wang, B., O’Brien, R. E., Kelly, S. T., Shilling, J. E., Moffet, R. C., Gilles, M. K., and Laskin, A.: Reactivity of liquid and semisolid secondary organic carbon with chloride and nitrate in atmospheric aerosols, J. Phys. Chem. A, 119, 4498-4508, https://doi.org/10.1021/jp510336q, 2015.

Wang, X., Jing, B., Tan, F., Ma, J., Zhang, Y., and Ge, M.: Hygroscopic behavior and chemical composition evolution of internally mixed aerosols composed of oxalic acid and ammonium sulfate, Atmos. Chem. Phys., 17, 12797-12812, https://doi.org/10.5194/acp-17-12797-2017, 2017.

Wang, Z., Jing, B., Shi, X., Tong, S., Wang, W., and Ge, M.: Importance of water-soluble organic acid on the hygroscopicity of nitrate, Atmos. Environ., 190, 65-73, https://doi.org/10.1016/j.atmosenv.2018.07.010, 2018.

Wu, L. and Ro, C.-U.: Aerosol Hygroscopicity on A Single Particle Level Using Microscopic and Spectroscopic Techniques: A Review, Asian J. Atmos. Environ., 14, 177-209, https://doi.org/10.5572/ajae.2020.14.3.177, 2020. 
Wu, L., Li, X., Kim, H., Geng, H., Godoi, R. H. M., Barbosa, C. G. G., Godoi, A. F. L., Yamamoto, C. I., de Souza, R. A. F., Pöhlker, C., Andreae, M. O., and Ro, C.-U.: Single-particle characterization of aerosols collected at a remote site in the Amazonian rainforest and an urban site in Manaus, Brazil, Atmos. Chem. Phys., 19, 1221-1240, https://doi.org/10.5194/acp19-1221-2019, 2019a.

Wu, L., Li, X., and Ro, C.-U.: Hygroscopic Behavior of Ammonium Sulfate, Ammonium Nitrate, and their Mixture Particles, Asian J. Atmos. Environ., 13, 196-211, https://doi.org/10.5572/ajae.2019.13.3.196, 2019b.

Wu, Z. J., Nowak, A., Poulain, L., Herrmann, H., and Wiedensohler, A.: Hygroscopic behavior of atmospherically relevant water-soluble carboxylic salts and their influence on the water uptake of ammonium sulfate, Atmos. Chem. Phys., 11, 1261712626, https://doi.org/10.5194/acp-11-12617-2011, 2011.

Yasmeen, F., Szmigielski, R., Vermeylen, R., Gomez-Gonzalez, Y., Surratt, J. D., Chan, A. W., Seinfeld, J. H., Maenhaut, W., and Claeys, M.: Mass spectrometric characterization of isomeric terpenoic acids from the oxidation of alpha-pinene, beta-pinene, $d$ limonene, and Delta3-carene in fine forest aerosol, J. Mass. Spectrom., 46, 425-442, https://doi.org/10.1002/jms.1911, 2011.
Yatavelli, R. L. N., Mohr, C., Stark, H., Day, D. A., Thompson, S. L., Lopez-Hilfiker, F. D., Campuzano-Jost, P., Palm, B. B., Vogel, A. L., Hoffmann, T., Heikkinen, L., Äijälä, M., Ng, N. L., Kimmel, J. R., Canagaratna, M. R., Ehn, M., Junninen, H., Cubison, M. J., Petäjä, T., Kulmala, M., Jayne, J. T., Worsnop, D. R., and Jimenez, J. L.: Estimating the contribution of organic acids to northern hemispheric continental organic aerosol, Geophys. Res. Lett., 42, 6084-6090, https://doi.org/10.1002/2015g1064650, 2015.

Zhang, Y. Y., Müller, L., Winterhalter, R., Moortgat, G. K., Hoffmann, T., and Pöschl, U.: Seasonal cycle and temperature dependence of pinene oxidation products, dicarboxylic acids and nitrophenols in fine and coarse air particulate matter, Atmos. Chem. Phys., 10, 7859-7873, https://doi.org/10.5194/acp-107859-2010, 2010. 